\title{
The impact of snow nitrate photolysis on boundary layer chemistry and the recycling and redistribution of reactive nitrogen across Antarctica and Greenland in a global chemical transport model
}

\author{
Maria Zatko $^{1}$, Lei Geng ${ }^{1}$, Becky Alexander ${ }^{1}$, Eric Sofen ${ }^{1, a}$, and Katarina Klein ${ }^{2}$ \\ ${ }^{1}$ Department of Atmospheric Sciences, University of Washington, Seattle, USA \\ ${ }^{2}$ Division of Glaciology, Alfred Wegener Institute Helmholtz Centre for Polar and Marine Research, Bremerhaven, Germany \\ ${ }^{a}$ now at: MathWorks, Natick, MA, USA
}

Correspondence to: Becky Alexander (beckya@uw.edu)

Received: 19 May 2015 - Published in Atmos. Chem. Phys. Discuss.: 10 July 2015

Revised: 9 February 2016 - Accepted: 11 February 2016 - Published: 4 March 2016

\begin{abstract}
The formation and recycling of reactive nitrogen $\left(\mathrm{NO}, \mathrm{NO}_{2}, \mathrm{HONO}\right)$ at the air-snow interface has implications for air quality and the oxidation capacity of the atmosphere in snow-covered regions. Nitrate $\left(\mathrm{NO}_{3}^{-}\right)$photolysis in snow provides a source of oxidants (e.g., hydroxyl radical) and oxidant precursors (e.g., nitrogen oxides) to the overlying boundary layer, and alters the concentration and isotopic $\left(\right.$ e.g., $\left.\delta^{15} \mathrm{~N}\right)$ signature of $\mathrm{NO}_{3}^{-}$preserved in ice cores. We have incorporated an idealized snowpack with a $\mathrm{NO}_{3}^{-}$photolysis parameterization into a global chemical transport model (Goddard Earth Observing System (GEOS) Chemistry model, GEOS-Chem) to examine the implications of snow $\mathrm{NO}_{3}^{-}$photolysis for boundary layer chemistry, the recycling and redistribution of reactive nitrogen, and the preservation of ice-core $\mathrm{NO}_{3}^{-}$in ice cores across Antarctica and Greenland, where observations of these parameters over large spatial scales are difficult to obtain. A major goal of this study is to examine the influence of meteorological parameters and chemical, optical, and physical snow properties on the magnitudes and spatial patterns of snowsourced $\mathrm{NO}_{x}$ fluxes and the recycling and redistribution of reactive nitrogen across Antarctica and Greenland. Snowsourced $\mathrm{NO}_{x}$ fluxes are most influenced by temperaturedependent quantum yields of $\mathrm{NO}_{3}^{-}$photolysis, photolabile $\mathrm{NO}_{3}^{-}$concentrations in snow, and concentrations of lightabsorbing impurities (LAIs) in snow. Despite very different assumptions about snowpack properties, the range of modelcalculated snow-sourced $\mathrm{NO}_{x}$ fluxes are similar in Greenland $\left(0.5-11 \times 10^{8}\right.$ molec $\left.\mathrm{cm}^{-2} \mathrm{~s}^{-1}\right)$ and Antarctica (0.01-
\end{abstract}

$6.4 \times 10^{8}$ molec $\mathrm{cm}^{-2} \mathrm{~s}^{-1}$ ) due to the opposing effects of higher concentrations of both photolabile $\mathrm{NO}_{3}^{-}$and LAIs in Greenland compared to Antarctica. Despite the similarity in snow-sourced $\mathrm{NO}_{x}$ fluxes, these fluxes lead to smaller factor increases in mean austral summer boundary layer mixing ratios of total nitrate $\left(\mathrm{HNO}_{3}+\mathrm{NO}_{3}^{-}\right), \mathrm{NO}_{x}, \mathrm{OH}$, and $\mathrm{O}_{3}$ in Greenland compared to Antarctica because of Greenland's proximity to pollution sources. The degree of nitrogen recycling in the snow is dependent on the relative magnitudes of snow-sourced $\mathrm{NO}_{x}$ fluxes versus primary $\mathrm{NO}_{3}^{-}$deposition. Recycling of snow $\mathrm{NO}_{3}^{-}$in Greenland is much less than in Antarctica Photolysis-driven loss of snow $\mathrm{NO}_{3}^{-}$is largely dependent on the time that $\mathrm{NO}_{3}^{-}$remains in the snow photic zone (up to 6.5 years in Antarctica and 7 months in Greenland), and wind patterns that redistribute snow-sourced reactive nitrogen across Antarctica and Greenland. The loss of snow $\mathrm{NO}_{3}^{-}$is higher in Antarctica (up to $99 \%$ ) than in Greenland (up to $83 \%$ ) due to deeper snow photic zones and lower snow accumulation rates in Antarctica. Modeled enrichments in ice-core $\delta^{15} \mathrm{~N}\left(\mathrm{NO}_{3}^{-}\right)$due to photolysis-driven loss of snow $\mathrm{NO}_{3}^{-}$ranges from 0 to $363 \%$ in Antarctica and 0 to $90 \%$ in Greenland, with the highest fraction of $\mathrm{NO}_{3}^{-}$ loss and largest enrichments in ice-core $\delta^{15} \mathrm{~N}\left(\mathrm{NO}_{3}^{-}\right)$at high elevations where snow accumulation rates are lowest. There is a strong relationship between the degree of photolysisdriven loss of snow $\mathrm{NO}_{3}^{-}$and the degree of nitrogen recycling between the air and snow throughout all of Greenland and in Antarctica where snow accumulation rates are greater than $130 \mathrm{~kg} \mathrm{~m}^{-2} \mathrm{a}^{-1}$ in the present day. 


\section{Introduction}

Nitrogen oxides $\left(\mathrm{NO}_{x}=\mathrm{NO}+\mathrm{NO}_{2}\right)$ emitted from fossil fuel combustion, biomass burning, soil microbial activity, and lightning have adverse respiratory effects, contribute to the formation of atmospheric acidity, and are a key ingredient in tropospheric oxidant cycling leading to the formation of ground-level ozone $\left(\mathrm{O}_{3}\right) . \mathrm{O}_{3}$ also has adverse respiratory effects, is an effective greenhouse gas (UNEP, 2011), and its photolysis dominates hydroxyl radical $(\mathrm{OH})$ production in much of the troposphere (Thompson, 1992). Oxidation to form nitrate $\left(\mathrm{HNO}_{3} / \mathrm{NO}_{3}^{-}\right)$is the main sink for $\mathrm{NO}_{x}$ in the troposphere (Logan, 1983), and the lifetime of $\mathrm{NO}_{x}$ against oxidation to nitrate is expected to be 1-3 days in polar regions (Levy et al., 1999). $\mathrm{NO}_{3}^{-}$is lost from the atmosphere through dry and wet deposition to the Earth's surface, and has a global atmospheric lifetime of roughly 5 days ( $\mathrm{Xu}$ and Penner, 2012). In Antarctica and Greenland, $\mathrm{HNO}_{3}$ and $\mathrm{NO}_{3}^{-}$ deposited to the snowpack originates from both the troposphere (e.g., long-range transport) (Geng et al., 2014a; Lee et al., 2014; Wespes et al., 2012) and stratosphere (Davidson et al., 1989; Frey et al., 2009; Savarino et al., 2007). In snowcovered regions, the deposition of $\mathrm{HNO}_{3}$ and $\mathrm{NO}_{3}^{-}$is not a permanent sink for $\mathrm{NO}_{x}$, as the photolysis of snow $\mathrm{NO}_{3}^{-}$returns reactive nitrogen $\left(\mathrm{N}_{\mathrm{r}}=\mathrm{NO}_{x}, \mathrm{HONO}\right)$ back to the atmosphere, with implications for other oxidants such as $\mathrm{OH}$ and $\mathrm{O}_{3}$ (Domine and Shepson, 2002).

Snow photochemistry significantly influences boundary layer chemistry and plays an important role in oxidant production and cycling, especially in pristine regions, such as Antarctica (Bloss et al., 2007; Chen et al., 2004, 2007; Grannas et al., 2007, Helmig et al., 2008; Sjostedt et al., 2007; Thomas et al., 2012). Snow photochemistry may have more widespread impacts since up to $40 \%$ of land on Earth is snow-covered at a given time (Grannas et al., 2007). $\mathrm{NO}_{3}^{-}$ is not the only photochemically active species in snow. The photolysis of nitrite $\left(\mathrm{NO}_{2}^{-}\right)$in snow and the photolysis of snow-sourced formaldehyde $\left(\mathrm{CH}_{2} \mathrm{O}\right)$, nitrous acid (HONO), and hydrogen peroxide $\left(\mathrm{H}_{2} \mathrm{O}_{2}\right)$ provide additional sources of $\mathrm{N}_{\mathrm{r}}$ and $\mathrm{OH}$ to the boundary layer. Bromine $\left(\mathrm{Br}_{2}\right)$ is also produced in the snow via reactions involving bromide $\left(\mathrm{Br}^{-}\right)$, photochemically active species (e.g., $\mathrm{NO}_{3}^{-}$), and photochemically produced species (e.g., $\mathrm{OH}$ ) within snow grains (Pratt et al., 2013).

In snow, $\mathrm{NO}_{3}^{-}$photolysis likely occurs in the liquid-like region (LLR) on the surface of ice grains, in cracks between ice grains, or in brine pockets embedded within ice grains (Domine et al., 2013). There are two channels for $\mathrm{NO}_{3}^{-}$ photolysis at wavelengths $(\lambda)=290-345 \mathrm{~nm}$. In the aqueous phase, $\mathrm{NO}_{3}^{-}$can photolyze to produce $\mathrm{NO}_{2}$ and $\mathrm{OH}$ (Eq. 1), or produce $\mathrm{NO}_{2}^{-}$and $\mathrm{O}\left({ }^{3} \mathrm{P}\right)$ (Eq. 2), but Eq. (1) is thought to be the dominant pathway (Grannas et al., 2007; Mack and Bolton, 1999; Meusinger et al., 2014).
$\mathrm{NO}_{3}^{-}(\mathrm{aq})+h v\left(+\mathrm{H}^{+}\right) \rightarrow \mathrm{NO}_{2}(\mathrm{aq})+\mathrm{OH}(\mathrm{aq})$

$\mathrm{NO}_{3}^{-}(\mathrm{aq})+h v \rightarrow \mathrm{NO}_{2}^{-}(\mathrm{aq})+\mathrm{O}\left({ }^{3} \mathrm{P}\right)(\mathrm{aq})$

The aqueous-phase $\mathrm{NO}_{2}$ produced in Eq. (1) can evaporate to the gas phase and be released into the interstitial air (Boxe et al., 2005) and subsequently be transported to the overlying atmosphere via diffusion and wind pumping (Zatko et al., 2013). The quantum yield $(\phi)$ in Eq. (1) is strongly influenced by the location of $\mathrm{NO}_{3}^{-}$in an ice grain. Quantum yields are more weakly dependent on LLR temperature and $\mathrm{pH} ; \phi$ values increase with increasing temperature and pH (Chu and Anastasio, 2003). Chu and Anastasio (2003) froze $\mathrm{NO}_{3}^{-}$-doped water in the lab and measured the quantum yield for Eq. (1) $\left(0.003\right.$ molec photon $^{-1}$ at $\left.T=253 \mathrm{~K}\right)$ as frozen ice grains were exposed to ultraviolet (UV) radiation. Zhu et al. (2010) deposited $\mathrm{HNO}_{3}$ on an ice film and measured $\phi$ for Eq. (1) $\left(0.6\right.$ molec photon $^{-1}$ at $T=253 \mathrm{~K}$ ), as the frozen surface was irradiated with UV radiation. A recent study by Meusinger et al. (2014) found $\phi=0.003-$ 0.44 molec photon $^{-1}$ at $T=258 \mathrm{~K}$ for Eq. (1), which nearly spans the full range of previously reported quantum yields. Results from Meusinger et al. (2014) suggest that $\phi$ is dependent on the length of time that snow is exposed to UV radiation, as well as the location of $\mathrm{NO}_{3}^{-}$in the ice grain. Meusinger et al. (2014) suggest that two photochemical domains of $\mathrm{NO}_{3}^{-}$exist: photolabile $\mathrm{NO}_{3}^{-}$and $\mathrm{NO}_{3}^{-}$buried within the ice grain. The $\mathrm{NO}_{x}$ produced from the photolysis of photolabile $\mathrm{NO}_{3}^{-}$can escape the ice grain, while the $\mathrm{NO}_{x}$ produced from the photolysis of buried $\mathrm{NO}_{3}^{-}$is likely to undergo recombination chemistry within the snow grain, thus lowering the quantum yield of $\mathrm{NO}_{x}$ for $\mathrm{NO}_{3}^{-}$photolysis. Recombination chemistry involves $\mathrm{NO}_{3}^{-}$reformation from photo-products (e.g., $\mathrm{NO}_{x}$ and $\mathrm{OH}$ ) within the ice grain, which alters oxygen isotopes (e.g., $\Delta^{17} \mathrm{O}$ ) of $\mathrm{NO}_{3}^{-}$, but does not impact bulk snow $\mathrm{NO}_{3}^{-}$concentrations nor its nitrogen isotopes $\left(\delta^{15} \mathrm{~N}\right)$ (Frey et al., 2009; Erbland et al., 2013, 2015).

The $\mathrm{NO}_{2}^{-}$produced in Eq. (2) is quickly photolyzed at longer wavelengths $(\lambda=290-390 \mathrm{~nm})$ in the LLR or can react with $\mathrm{OH}$ or $\mathrm{H}^{+}$in the LLR to produce $\mathrm{N}_{\mathrm{r}}$ (Grannas et al., 2007):

$$
\begin{aligned}
& \mathrm{NO}_{2}^{-}(\mathrm{aq})+h v\left(+\mathrm{H}^{+}, \mathrm{aq}\right) \rightarrow \mathrm{NO}(\mathrm{aq})+\mathrm{OH}(\mathrm{aq}), \\
& \mathrm{NO}_{2}^{-}(\mathrm{aq})+\mathrm{OH}(\mathrm{aq}) \rightarrow \mathrm{NO}_{2}(\mathrm{aq})+\mathrm{OH}^{-}(\mathrm{aq}), \\
& \mathrm{NO}_{2}^{-}(\mathrm{aq})+\mathrm{H}^{+}(\mathrm{aq}) \rightarrow \mathrm{HONO}(\mathrm{aq}) .
\end{aligned}
$$

HONO produced in Eq. (5) can rapidly photolyze to produce $\mathrm{NO}$ and $\mathrm{OH}$ in the interstitial air or the atmospheric boundary layer (Anastasio and Chu, 2009). Reactions involving $\mathrm{NO}_{2}^{-}$are intermediate reactions for $\mathrm{NO}_{3}^{-}$photolysis because $\mathrm{NO}_{3}^{-}$photolysis is required for $\mathrm{NO}_{2}^{-}$formation and the end products of Eqs. (1)-(5) are all $\mathrm{N}_{\mathrm{r}}$. Once produced, $\mathrm{NO}_{2}$ and NO can be efficiently transported to the overlying atmosphere via wind pumping (Zatko et al., 2013) and enter into 
rapid $\mathrm{NO}_{x}$-cycling reactions. In the atmosphere, the relative abundance of $\mathrm{NO}$ and $\mathrm{NO}_{2}$ will be determined by local atmospheric conditions, specifically oxidant concentrations (e.g., $\mathrm{O}_{3}, \mathrm{HO}_{2}, \mathrm{RO}_{2}, \mathrm{BrO}$, and $\mathrm{ClO}$ ) (Frey et al., 2013). The snowsourced $\mathrm{NO}_{x}$ can be re-oxidized to $\mathrm{HNO}_{3}$ via Eq. (6) under sunlit conditions.

$\mathrm{NO}_{2}(\mathrm{~g})+\mathrm{OH}(\mathrm{g}) \rightarrow \mathrm{HNO}_{3}(\mathrm{~g})$

The $\mathrm{HNO}_{3}$ produced in Eq. (6) can undergo wet or dry deposition to the snow surface (Dibb et al., 2004) within a day (Slusher et al., 2002; Wang et al., 2008). Evidence for $\mathrm{HNO}_{3}$ re-deposition is seen in the snow $\mathrm{NO}_{3}^{-}$concentration profile at many polar locations, where $\mathrm{NO}_{3}^{-}$concentrations may be over an order of magnitude higher in the top $2 \mathrm{~cm}$ of snow compared to $\mathrm{NO}_{3}^{-}$concentrations below (Dibb et al., 2004; Frey et al., 2009; Mayewski and Legrand, 1990; Rothlisberger et al., 2000).

Once $\mathrm{HNO}_{3}$ is deposited back to the snow, it is available for photolysis again. $\mathrm{NO}_{3}^{-}$can be recycled multiple times between the boundary layer and the snow before burial below the photochemically active region, known as the snow photic zone (Davis et al., 2008; Erbland et al., 2015). Only two previous studies have attempted to quantify the degree of nitrogen recycling between the air and snow. Davis et al. (2008) use estimates of atmospheric $\mathrm{NO}_{x}$ overheadcolumn burdens, as well as average atmospheric $\mathrm{NO}_{x}$ lifetimes along with primary nitrogen deposition measurements from Legrand and Kirchner (1990), to estimate that nitrogen is recycled 1.8 times on average between the air and snow in one photochemical season in East Antarctica, although this value may be 3-5 times higher due to uncertainties in primary nitrogen deposition estimates. Erbland et al. (2015) used a multi-layer, one-dimensional (1-D) snow model (TRANSITS, Transfer of Atmospheric Nitrate Stable Isotopes To the Snow) and calculated that nitrogen is recycled 4 times on average before burial beneath the snow photic zone. Erbland et al. (2015) observed an inverse relationship between snow accumulation rate and nitrogen recycling in regions where snow accumulation rates are greater than $50 \mathrm{~kg} \mathrm{~m}^{-2} \mathrm{a}^{-1}$, and suggest that in these regions, the degree of $\mathrm{NO}_{3}^{-}$recycling is governed by the time $\mathrm{NO}_{3}^{-}$remains in the snow photic zone.

The photolysis of snow $\mathrm{NO}_{3}^{-}$and subsequent recycling between the air and snow alters the concentration and isotopic (e.g., $\left.\delta^{15} \mathrm{~N}\right)$ signature of $\mathrm{NO}_{3}^{-}$that is ultimately preserved in polar ice sheets, which hampers the interpretation of ice-core $\mathrm{NO}_{3}^{-}$records (Wolff et al., 2008). Such records have been sought to reconstruct the past history of the abundance of $\mathrm{NO}_{x}$ in the atmosphere (Wolff, 1995). It has also been suggested that the nitrogen $\left(\delta^{15} \mathrm{~N}\right)$ and oxygen $\left(\Delta^{17} \mathrm{O}\right)$ isotopic composition of ice-core $\mathrm{NO}_{3}^{-}$can provide information on past variability in atmospheric $\mathrm{NO}_{x}$ sources and oxidant abundances (e.g., Alexander et al., 2004; Hastings et al., 2005). Different sources of $\mathrm{NO}_{x}$ have different $\delta^{15} \mathrm{~N}$ signatures ( $\sim-19$ to $25 \%$ o, Geng et al., 2014a; Walters et al.,
2015), giving ice-core $\delta^{15} \mathrm{~N}\left(\mathrm{NO}_{3}^{-}\right)$measurements the potential to track $\mathrm{NO}_{x}$-source changes over time.

Ice-core $\delta^{15} \mathrm{~N}\left(\mathrm{NO}_{3}^{-}\right)$values will be altered if there is photolysis-driven loss of $\mathrm{NO}_{3}^{-}$from the snow when snowsourced $\mathrm{NO}_{x}$ is transported away from the site of primary deposition. $\mathrm{NO}_{3}^{-}$photolysis in snow is associated with a large fractionation constant $(\varepsilon$, e.g., $-47.9 \%$; Berhanu et al., 2014), providing the boundary layer with a source of $\mathrm{NO}_{x}$ that is highly depleted in $\delta^{15} \mathrm{~N}\left(\mathrm{NO}_{3}^{-}\right)$, leaving highly enriched $\delta^{15} \mathrm{~N}_{\left(\mathrm{NO}_{3}^{-}\right)}$in the snow. In Antarctica, atmospheric $\delta^{15} \mathrm{~N}\left(\mathrm{NO}_{3}^{-}\right)$values at the coast are as low as $-40 \%$, indicating transport of snow-sourced $\mathrm{NO}_{x}$ from the continental interior (Morin et al., 2009), while on the East Antarctica plateau, snow $\delta^{15} \mathrm{~N}\left(\mathrm{NO}_{3}^{-}\right)$up to $480 \%$ o has been reported (Blunier et al., 2005; Erbland et al., 2013; Frey et al., 2009; Shi et al., 2014), indicating net loss of $\mathrm{NO}_{3}^{-}$-driven by photolysis. In Greenland, atmospheric $\delta^{15} \mathrm{~N}\left(\mathrm{NO}_{3}^{-}\right)$values are much less depleted (as low as $-15 \%$ ) and snow $\delta^{15} \mathrm{~N}\left(\mathrm{NO}_{3}^{-}\right.$) values are much less enriched (as high as 15\%o) compared to these extreme values observed in coastal Antarctica and on the East Antarctic plateau (Geng et al., 2014a; Hastings et al., 2004; Jarvis et al., 2009).

If snow-sourced $\mathrm{NO}_{x}$ is simply re-deposited back to the snow surface at the site of emission, a vertical profile in $\delta^{15} \mathrm{~N}\left(\mathrm{NO}_{3}^{-}\right)$within the snow photic zone will develop due to vertical redistribution of $\mathrm{NO}_{3}^{-}$(Erbland et al., 2013; Frey et al., 2009); however, the depth-integrated $\delta^{15} \mathrm{~N}\left(\mathrm{NO}_{3}^{-}\right)$will not be impacted, even with active photolysis-driven recycling between the atmosphere and the snow. Enrichment in ice-core $\delta^{15} \mathrm{~N}\left(\mathrm{NO}_{3}^{-}\right)$requires photolysis-driven loss from snow from net atmospheric transport of snow-sourced $\mathrm{NO}_{x}$ away from the locations of its production. In addition to photolysis, icecore $\delta^{15} \mathrm{~N}\left(\mathrm{NO}_{3}^{-}\right)$values are also influenced by evaporation of $\mathrm{HNO}_{3}$ (Mulvaney et al., 1998) from snow and by atmospheric processing, such as $\mathrm{NO}_{x}$ cycling (Freyer et al., 1993) and gas-particle partitioning (Heaton et al., 1997; Geng et al., 2014a); however, these impose a fractionation in $\delta^{15} \mathrm{~N}\left(\mathrm{NO}_{3}^{-}\right)$ at least an order of magnitude smaller than photolysis, and are thus not able to explain the large enrichments in snow $\delta^{15} \mathrm{~N}\left(\mathrm{NO}_{3}^{-}\right)$observed on the East Antarctic plateau (Blunier et al., 2005; Erbland et al., 2013; Frey et al., 2009; Shi et al., 2014).

Here we incorporate an idealized snowpack with a $\mathrm{NO}_{3}^{-}$ photolysis parameterization into a global chemical transport model. The idealized Antarctic and Greenland ice sheets in the model have similar properties as the real ice sheets, but are subject to assumptions about the chemical and physical properties of the snow. The idealized snowpacks in this modeling framework attempt to account for the spatial variability in parameters important to snow $\mathrm{NO}_{3}^{-}$photolysis in order to investigate the potential spatial variability in snowsourced $\mathrm{NO}_{x}$ fluxes, reactive nitrogen recycling and redistribution, and preservation of ice-core $\mathrm{NO}_{3}^{-}$across Antarctica and Greenland, where observations of these parameters over 
Table 1. Glossary of variables used in this paper.

\begin{tabular}{|c|c|c|}
\hline Variable & Unit & Description \\
\hline$\lambda$ & $\mathrm{nm}$ & Wavelength \\
\hline$\phi$ & molec photon $^{-1}$ & Quantum yield for $\mathrm{NO}_{3}^{-}$photolysis \\
\hline$\sigma_{\mathrm{NO}_{3}^{-}}$ & $\mathrm{cm}^{2}$ & Absorption cross-section for $\mathrm{NO}_{3}^{-}$photolysis \\
\hline$I^{3}$ & photons $\mathrm{cm}^{-2} \mathrm{~s}^{-1} \mathrm{~nm}^{-1}$ & Actinic flux of UV radiation \\
\hline$z \mathrm{e}$ & $\mathrm{cm}$ & $e$-folding depth of UV actinic flux in snow \\
\hline$z_{3 \mathrm{e}}$ & $\mathrm{cm}$ & Depth of snow photic zone \\
\hline$\alpha_{\mathrm{r}}$ & $\mathrm{kg} \mathrm{m}^{-2}$ year $^{-1}$ & Total annual snow accumulation rate \\
\hline$C_{\mathrm{BC}}$ & $\operatorname{ngg}^{-1}$ & Annual mean snow black carbon concentration \\
\hline$r_{\mathrm{e}}$ & $\mu \mathrm{m}$ & Radiation equivalent mean ice grain radii \\
\hline$\rho_{\text {snow }}$ & $\mathrm{kg} \mathrm{m}^{-3}$ & Snow density \\
\hline Kext $_{\text {tot }}$ & $\mathrm{cm}^{-1}$ & Bulk extinction coefficient for snow \\
\hline$\left[\mathrm{NO}_{3}^{-}\right]_{\text {top }}$ & $\operatorname{ngg}^{-1}$ & Mean $\mathrm{NO}_{3}^{-}$concentration in top $2 \mathrm{~cm}$ of snow \\
\hline$\left[\mathrm{NO}_{3}^{-}\right]_{\text {bot }}$ & $\operatorname{ngg}^{-1}$ & Mean $\mathrm{NO}_{3}^{-\frac{3}{3}}$ concentration in below $2 \mathrm{~cm}$ snow depth \\
\hline $\mathrm{EF}$ & unitless & $\mathrm{NO}_{3}^{-}$enhancement factor in top $2 \mathrm{~cm}$ of snow \\
\hline$F_{\mathrm{p}}$ & fraction & Fraction of photolabile $\mathrm{NO}_{3}^{-}$in snow \\
\hline$\left[\mathrm{NO}_{3}^{-}\right]_{\mathrm{bot}} \times F_{\mathrm{p}}$ & $\operatorname{ng~g}^{-1}$ & $\begin{array}{l}\text { Mean } \mathrm{NO}_{3}^{-} \text {concentration from } 2 \mathrm{~cm} \text { depth to the bottom of the snow photic zone } \\
\text { scaled by fraction of photolabile } \mathrm{NO}_{3}^{-} \text {in snow }\end{array}$ \\
\hline$\varepsilon$ & $\%$ & Fractionation constant for $\mathrm{NO}_{3}^{-}$photolysis \\
\hline$\overline{F_{\mathrm{NO}_{x}}}$ & molec $\mathrm{cm}^{-2} \mathrm{~s}^{-1}$ & Mean austral summer flux of snow-sourced $\mathrm{NO}_{x}$ \\
\hline$F_{\mathrm{NO}_{x}}$ & $\operatorname{ng~} \mathrm{N} \mathrm{m}^{-2}$ year $^{-1}$ & Annual sum of snow-sourced $\mathrm{NO}_{x}$ flux \\
\hline$F_{\text {PRI }}$ & $\operatorname{ng~} \mathrm{N} \mathrm{m}^{-2}$ year $^{-1}$ & Annual sum of primary $\mathrm{NO}_{3}^{-}$deposited to snow \\
\hline$F_{\mathrm{R}}$ & $\operatorname{ng~} \mathrm{N} \mathrm{m}^{-2}$ year $^{-1}$ & Annual sum of recycled $\mathrm{NO}_{3}^{-}$to snow \\
\hline NRF & unitless & Metric to assess degree of nitrogen recycling in 1 year \\
\hline$\tau \mathrm{NO}_{3 \text { burial }}^{-}$ & years/months & Lifetime of $\mathrm{NO}_{3}^{-}$against burial below snow photic zone \\
\hline$\tau_{\mathrm{NO}_{3}^{-} \text {photolysis }}$ & months & Lifetime of $\mathrm{NO}_{3}^{-}$against photolysis in snow photic zone \\
\hline$F_{\mathrm{p}_{\text {photo }}}$ & unitless & Fraction of photolabile $\mathrm{NO}_{3}^{-}$photolyzed rather than buried below the snow photic zone \\
\hline$f$ & fraction & Fraction of photolysis-driven loss of $\mathrm{NO}_{3}^{-}$from snow \\
\hline$\delta^{15} \mathrm{~N}\left(\mathrm{NO}_{3}^{-}\right)$ & $\% 0$ & Nitrogen isotopic composition of $\mathrm{NO}_{3}^{-}$ \\
\hline
\end{tabular}

large spatial scales are difficult to obtain. A major advantage of using a global chemical transport model framework is the ability to examine the potential redistribution and loss of reactive nitrogen due to photolysis-driven loss of snow $\mathrm{NO}_{3}^{-}$ across large spatial scales. The sensitivity of many parameters, such as snow accumulation rate, on the flux of snowsourced $\mathrm{NO}_{x}$, nitrogen recycling, and loss of snow $\mathrm{NO}_{3}^{-}$is elucidated by comparing modeled results in Antarctica and Greenland. Section 2 describes the inclusion of an idealized snowpack with a snow $\mathrm{NO}_{3}^{-}$photolysis parameterization into a global chemical transport model, Goddard Earth Observing System (GEOS) Chemistry model (GEOS-Chem). Section 3 explores the implications of photolysis-driven reactive nitrogen recycling and redistribution for boundary layer chemistry and the alteration of $\mathrm{NO}_{3}^{-}$concentration and its nitrogen isotopes $\left(\delta^{15} \mathrm{~N}\right)$ ultimately archived in ice cores. In Sect. 3, we also compare model results in Antarctica and Greenland to examine the sensitivity of the flux of snow-sourced $\mathrm{NO}_{x}$ and associated photolysis-driven processes on meteorological parameters and various chemical, optical, and physical proper- ties of snow. We end Sect. 3 by discussing results from our model sensitivity studies that highlight the largest uncertainties in our ability to model these processes. Section 4 summarizes our conclusions and provides recommendations for future laboratory and field studies based on our model sensitivity results.

\section{Methods}

\subsection{Incorporating snow $\mathrm{NO}_{3}^{-}$photolysis into a global chemical transport model}

Table 1 provides a glossary of the variables used throughout this paper and Table 2 shows the values of parameters used in this modeling study.

\subsubsection{Global chemical transport model description}

GEOS-Chem is a global 3-D model of coupled aerosoloxidant chemistry with detailed $\mathrm{HO}_{x}-\mathrm{NO}_{x}-\mathrm{VOC}-\mathrm{O}_{3}-\mathrm{BrO}_{x}$ tropospheric chemistry originally described in Bey et 
al. (2001). The model uses assimilated meteorological data from the NASA Goddard Earth Observing System (GEOS5) including winds, convective mass fluxes, boundary layer depths, temperature, precipitation, and surface properties. Meteorological data have $6 \mathrm{~h}$ temporal resolution $(3 \mathrm{~h}$ for surface variables and mixing depths). The TPCORE advection algorithm (Lin and Rood, 1996) is the transport routine in GEOS-Chem and is based on the calculation of the slopes between neighboring grid boxes. At the poles, neighboring grid boxes are used to estimate transport of chemical species into and out of the circular polar grid box. In Figs. 2-11, data in each grid box are smoothed using bilinear interpolation. The spectral direct and diffuse downwelling surface irradiance and photolysis frequencies are calculated using the Fast-JX radiative transfer module (Bian and Prather, 2002; Mao et al., 2010; Wild et al., 2000). In GEOS-Chem, aerosols can be wet deposited via scavenging in convective updrafts and by rainout from convective anvils and large-scale precipitation (Liu et al., 2001). The wet deposition scheme for gases is described by Amos et al. (2012) and the scavenging of aerosol by snow and cold/mixed precipitation is described by Wang et al. (2011). Dry-deposition velocities for coarsemode aerosols (radii between 1 and $10 \mathrm{~mm}$ ) are calculated based on aerosol size and hydroscopic growth as described in Zhang et al. (2001). Aerosol deposition to snow and ice surfaces is described by Fisher et al. (2011). For smaller aerosols (radii less than $1 \mu \mathrm{m}$ ), dry deposition velocities are calculated with a standard resistance-in-series scheme (Wang et al., 1998; Wesely, 1989).

Anthropogenic $\mathrm{NO}_{x}$ emissions are from the EDGAR (Emission Database for Global Atmospheric Research) 3.2FT2000 global inventory for the year 2000 (Oliver et al., 2005), scaled by country on the basis of energy statistics as described by van Donkelaar et al. (2008). The monthly inventory of emissions from biomass burning are from the Global Fire Emissions Database (GFED2) (van der Werf et al., 2009). Soil $\mathrm{NO}_{x}$ emissions are computed using a parameterization described in Hudman et al. (2012), which is a function of vegetation type, temperature, soil moisture, precipitation, and fertilizer emissions. Emissions of $\mathrm{NO}_{x}$ from lightning are linked to deep convection following the parameterization of Price and Rind (1992) and are scaled globally as described by Murray et al. (2012) to match OTD/LIS climatological observations of lightning flashes. The stratospheric source of $\mathrm{NO}_{y}\left(=\mathrm{NO}_{x}+\mathrm{HNO}_{3}\right)$ utilizes monthly climatological 3-D production and loss rates from the Global Modeling Initiative (GMI) model (Allen et al., 2010), which captures the formation of the polar vortex and PSC (polar stratospheric cloud) sedimentation (Murray et al., 2012).

For this work, GEOS-Chem version v9-01-01 was run at $2^{\circ} \times 2.5^{\circ}$ horizontal resolution with 72 hybrid vertical levels using GEOS-5 meteorology from May 2009 to May 2010. The model was spun-up for 6 months prior to May 2009. There are no sub-surface (snow) layers in GEOS-Chem and the three lowest vertical levels are each roughly $100 \mathrm{~m}$ in

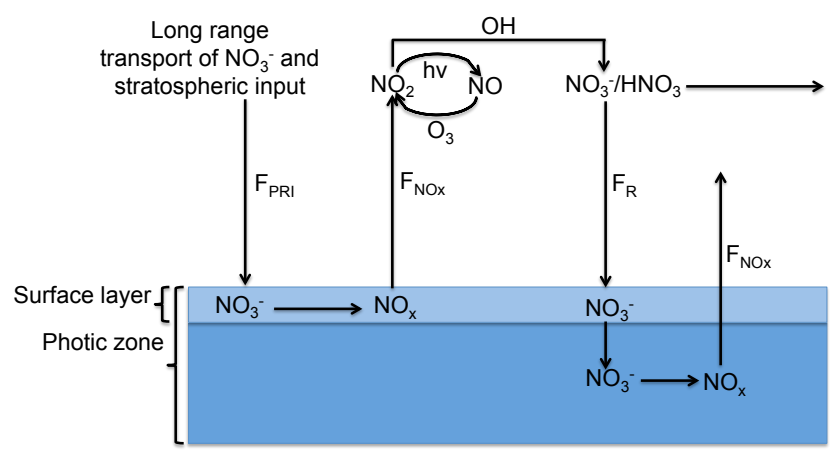

Figure 1. Schematic showing the nitrogen recycling associated with $\mathrm{NO}_{3}^{-}$photolysis as included in the model. $F_{\mathrm{PRI}}\left(\mathrm{ng} \mathrm{N} \mathrm{m}^{-2} \mathrm{yr}^{-1}\right)$ is the downward, primary flux of $\mathrm{NO}_{3}^{-}$to Antarctica and Greenland originating from long-range transport and the stratosphere, $F_{\mathrm{NO}_{x}}$ (ng $\mathrm{N} \mathrm{m}^{-2} \mathrm{yr}^{-1}$ ) is the upward flux of snow-sourced $\mathrm{NO}_{x}$ to the boundary layer, and $F_{\mathrm{R}}\left(\mathrm{ng} \mathrm{N} \mathrm{m} \mathrm{Nr}^{-2}\right)$ is downward, recycled flux of $\mathrm{HNO}_{3}$ to the snow surface. The surface snow layer (top $2 \mathrm{~cm}$ ) is distinguished from the rest of the photic zone because 30 $65 \%$ of snow-sourced $\mathrm{NO}_{x}$ is produced in the top $2 \mathrm{~cm}$ of snowpack (Zatko et al., 2013), and because both $\mathrm{NO}_{3}^{-}$concentrations and actinic flux are much higher in the top surface layer compared to deeper layers.

height above Antarctica. The boundary layer in GEOS-Chem is calculated using a parameterization involving the bulk Richardson number with surface friction, a turbulent velocity scale, and non-local fluxes of heat and moisture (Holtslag and Boville, 1993) as implemented by Lin and McElroy (2010). The mixing of emissions, dry deposition, and concentrations of individual species within the boundary layer are determined by static instability. In a stable boundary layer, the local scheme based on eddy diffusivity theory is used, and the mixing is weak. In an unstable boundary layer, boundary layer mixing is triggered by large eddies. Average boundary layer mixing ratios (ppbv) of species reported in this study (e.g., $\mathrm{NO}_{3}^{-}, \mathrm{NO}_{x}, \mathrm{OH}, \mathrm{O}_{3}$ ) are mixing ratios in the lowest vertical grid box (total height $\sim 100 \mathrm{~m}$ ).

Figure 1 illustrates the nitrogen recycling associated with snow $\mathrm{NO}_{3}^{-}$photolysis as included in the model. The total flux of snow-sourced $\mathrm{NO}_{x}$ from the snow, $F_{\mathrm{NO}_{x}}\left(\right.$ molec $\left.\mathrm{cm}^{-2} \mathrm{~s}^{-1}\right)$, is calculated using the wavelength-dependent absorption cross section for $\mathrm{NO}_{3}^{-}$ photolysis $\left(\sigma_{\mathrm{NO}_{3}}^{-}, \mathrm{cm}^{2}\right.$ molec $\left.^{-1}\right)$, the temperature $(T)^{-}$, and $\mathrm{pH}$-dependent quantum yield for $\mathrm{NO}_{3}^{-}$photolysis $\left(\phi\right.$, molec photon $\left.{ }^{-1}\right)$, the depth- and wavelengthdependent actinic flux in the snow photic zone ( $I$, photons $\mathrm{cm}^{-2} \mathrm{~s}^{-1} \mathrm{~nm}^{-1}$ ), and the average $\mathrm{NO}_{3}^{-}$concentration $\left[\mathrm{NO}_{3}^{-}\right]$, molec $\mathrm{cm}^{-3}$ ) integrated over the depth of the photic zone. $F_{\mathrm{NO}_{x}}\left(\right.$ molec $\left.\mathrm{cm}^{-2} \mathrm{~s}^{-1}\right)$ is calculated in Eq. (7) and converted into units of $\mathrm{ng} \mathrm{N} \mathrm{m}^{-2} \mathrm{yr}^{-1}$ in Eqs. (9) and (10). 


$$
F_{\mathrm{NO}_{x}}=\int_{\lambda_{0}}^{\lambda_{1}} \int_{z_{0}}^{z_{3 e}} J(\lambda, z) \cdot\left[\mathrm{NO}_{3}^{-}\right] \mathrm{d} \lambda \mathrm{d} z,
$$

where $\left[\mathrm{NO}_{3}^{-}\right]$is the average photolabile $\mathrm{NO}_{3}^{-}$concentration over the depth of the snow photic zone $\left(z=z_{0}\right.$ to $\left.z=z_{3 \mathrm{e}}\right)$ and $J$ is the photolysis rate constant $\left(\mathrm{s}^{-1}\right)$, which is calculated in Eq. (8):

$J=\sigma_{\mathrm{NO}_{3}^{-}}(\lambda) \cdot \phi(T, \mathrm{pH}) \cdot I(\lambda, z)$.

In Eq. (8), $\sigma_{\mathrm{NO}_{3}}^{-}$is from Sander et al. (2006). The temperature-dependent $\phi$ from Chu and Anastasio (2003) (assumed constant $\mathrm{pH}$ of 5) is calculated using the modeled air temperature in the lowest vertical grid box. The actinic flux $(I)$ is calculated at $1 \mathrm{~cm}$ intervals and integrated from the snow surface $\left(z_{0}\right)$ to the depth of the photic zone $\left(z_{3 \mathrm{e}}\right)$. The snow photic zone is defined as 3 times the $e$-folding depth of ultraviolet (UV) actinic flux in snow $\left(z_{3 e}\right)$, where $1 e$-folding depth is $z_{\mathrm{e}}$. Below $z_{3 \mathrm{e}}$, more than $95 \%$ of the radiation has been attenuated and minimal photochemistry occurs. The flux of snow-sourced $\mathrm{NO}_{x}$ is integrated over several ultraviolet wavelength bands (298-307, 307-312, 312$320,320-345 \mathrm{~nm}$ ), which are then summed to calculate total $F_{\mathrm{NO}_{x}}$ from the photolysis of snow $\mathrm{NO}_{3}^{-}$between $\lambda=298$ $345 \mathrm{~nm}$. We assume that all $\mathrm{NO}_{x}$ formed in Eq. (7) is immediately evaporated and transported into the overlying boundary layer via wind pumping and diffusion (Zatko et al., 2013).

\subsubsection{Calculating radiative transfer in snow}

A two-stream, plane parallel snowpack actinic flux parameterization based on a four-stream radiative transfer model (Grenfell, 1991) was developed and described in detail in Zatko et al. (2013) and has been implemented into GEOSChem for the purposes of this study. The parameterization is simple, broadly applicable, and allows for variation in snow and sky properties (e.g., solar zenith angle, cloud fraction) over time. Ice grains are assumed to be spherical in shape and light-absorbing impurities (LAIs), including black carbon, brown carbon, dust, and organics, are assumed to be homogeneously distributed throughout the snow and always external to the ice grain. The snowpack actinic flux parameterization is used to calculate the UV actinic flux (photons $\mathrm{cm}^{-2} \mathrm{~s}^{-1} \mathrm{~nm}^{-1}$ ) and the mean summer $e$-folding depths (cm) across Antarctica and Greenland, which are used to calculate $F_{\mathrm{NO}_{x}}$. The snowpack actinic flux parameterization is most sensitive to radiation equivalent mean ice grain radii $\left(r_{\mathrm{e}}\right)$ and insoluble LAIs in snow (Zatko et al., 2013); higher concentrations of LAIs in the snow and smaller $r_{\mathrm{e}}$ lead to shallower $e$-folding depths $\left(z_{\mathrm{e}}\right)$. Vertical $r_{\mathrm{e}}$ and snow density $\left(\rho_{\text {snow }}\right)$ profiles at Dome C, Antarctica, from Gallet et al. (2011) are used across Antarctica for all seasons, which range from 86 to $235 \mu \mathrm{m}$ and 260 to $360 \mathrm{~kg} \mathrm{~m}^{-3}$, from the snow surface to $300 \mathrm{~cm}$ depth, respectively. Vertical $r_{\mathrm{e}}$ and $\rho_{\text {snow }}$ profiles at Summit, Greenland, from Carmagnola et al. (2013) are used in Greenland, ranging from 73 to $211 \mu \mathrm{m}$ and 235 to $350 \mathrm{~kg} \mathrm{~m}^{-3}$, from the snow surface to $300 \mathrm{~cm}$ depth, respectively.

The concentration of black carbon (BC) concentrations in snow $\left(C_{\mathrm{BC}}\right)$ are calculated using modeled total annual black carbon (hydrophilic + hydrophobic) deposition (ng $\mathrm{BC} \mathrm{m}^{-2} \mathrm{yr}^{-1}$ ) and total annual snow accumulation rates $\left(\mathrm{g} \mathrm{H}_{2} \mathrm{O} \mathrm{m}^{-2} \mathrm{yr}^{-1}\right)$ in GEOS-Chem. At some locations in coastal Antarctica, high accumulation rates (up to $700 \mathrm{~kg} \mathrm{~m}^{-2} \mathrm{yr}^{-1}$ ) lead to unrealistically low $C_{\mathrm{BC}}$ (as low as $0.01 \mathrm{ng} \mathrm{g}^{-1}$ ), therefore the minimum $C_{\mathrm{BC}}$ value used in the model is $0.08 \mathrm{ng} \mathrm{g}^{-1}$, which is comparable to the $C_{\mathrm{BC}}$ values measured in high snow accumulation rate regions, such as in the East Antarctic sea ice zone $\left(0.1 \mathrm{ng} \mathrm{g}^{-1}\right)$ (Zatko and Warren, 2015). Insoluble non-black carbon species (nonBC) including dust, brown carbon, and organics, are responsible for the majority (up to $89 \%$ at $\lambda=305 \mathrm{~nm}$ ) of the absorption of radiation at UV wavelengths (Zatko et al., 2013) in snow. These nonBC species and their concentrations have not been well quantified in snow. Based on observations reported in Zatko et al. (2013), we scale UV absorption by insoluble nonBC to the absorption by insoluble black carbon in snow by assuming that at $\lambda=650-700 \mathrm{~nm}$, which is a wavelength range where black carbon dominates absorption, insoluble black carbon is responsible for $70 \%$ of the particulate absorption. We also assume that nonBC material has an absorption Ångström exponent of 5 (Doherty et al., 2010).

We neglect the influence of soluble LAIs in the snow and only consider the influence of insoluble LAIs for calculations of actinic flux profiles in snow. To determine whether soluble LAIs contribute significantly to light-absorption in the snow, we calculate the total extinction coefficient for insoluble BC, insoluble nonBC, and soluble LAIs following Sect. 2.1 of Zatko et al. (2013) and using the absorption coefficients for soluble material in snow reported in Beine et al. (2011) in northern Alaska. To our knowledge, observations of soluble LAI in Antarctic and Greenland snow are unavailable. We use soluble LAI observations from Alaska to provide a relative estimate of the importance of soluble LAIs in polar snow. The absorption coefficients $\left(0.028 \mathrm{~m}^{-1}\right.$ at $\left.\lambda=307 \mathrm{~nm}\right)$ from Beine et al. (2011) are identical to the extinction coefficients because it is assumed that there is no scattering by soluble species. Insoluble $C_{\mathrm{BC}}\left(9 \mathrm{ng} \mathrm{g}^{-1}\right)$ from Barrow, Alaska (Doherty et al., 2010), were used to calculate extinction coefficients for insoluble $\mathrm{BC}$ and nonBC material and therefore the amount of nonBC absorption in the UV and near-visible wavelengths following Zatko et al. (2013). Insoluble nonBC material is responsible for 9-14 times more absorption than soluble material in the wavelength range $\lambda=298-345 \mathrm{~nm}$. Insoluble $\mathrm{BC}$ material is responsible for 1.5-10 times more absorption than soluble material in the wavelength range $\lambda=298-345 \mathrm{~nm}$. The extinction coefficient is not influenced by the addition of a soluble absorber because scattering by 
snow grains dominates the extinction in snow. The effective co-albedo of single scattering is increased by $6-15 \%$ when soluble absorbers are included. The resulting change in $z_{\mathrm{e}}$ is at most $0.5 \mathrm{~cm}$, which represents an increase of $4-9 \%$ in the wavelength region of $\lambda=298-345 \mathrm{~nm}$.

\subsubsection{Calculating $\mathrm{NO}_{3}^{-}$concentrations in snow}

The median value of sub-surface snow $\mathrm{NO}_{3}^{-}$concentrations is $60 \mathrm{ng} \mathrm{g}^{-1}$ in Antarctica (Bertler et al., 2005) and $132 \mathrm{ng} \mathrm{g}^{-1}$ in Greenland (Burkhart et al., 2009). Snow $\mathrm{NO}_{3}^{-}$ was collected over depths corresponding to between 1 and 70 year(s) of snow accumulation in Antarctica and between 1 and 148 year(s) of snow accumulation in Greenland. The observed median values of sub-surface snow $\mathrm{NO}_{3}^{-}$concentrations are used for modeled sub-surface (from $2 \mathrm{~cm}$ depth to the bottom of the snow photic zone, $z_{3 \mathrm{e}}$ ) snow $\mathrm{NO}_{3}^{-}$concentrations ( $\left.\left[\mathrm{NO}_{3}^{-}\right]_{\text {bot }}\right)$ across Antarctica and Greenland. Although there is a large variation in observed snow $\mathrm{NO}_{3}^{-}$ concentrations from the ITASE campaign (Bertler et al., 2005), there is no clear spatial pattern across Antarctica. In Greenland, the relationship between snow accumulation rate and snow $\mathrm{NO}_{3}^{-}$concentrations is non-linear and snow accumulation alone cannot account for the spatial variability in $\mathrm{NO}_{3}^{-}$concentrations in lower snow accumulation rate regions (Burkhart et al., 2009). In Antarctica, snow $\mathrm{NO}_{3}^{-}$concentrations in the top $2 \mathrm{~cm}$ of snow are up to 10 times higher than $\mathrm{NO}_{3}^{-}$concentrations below 2-cm depth (Dibb et al., 2004; Erbland et al., 2013; Frey et al., 2009; Mayewski and Legrand, 1990; Rothlisberger et al., 2000), while in Greenland, surface snow layers are at most 2 times higher compared to sub-surface snow layers (Dibb et al., 2007). In this study, $\mathrm{NO}_{3}^{-}$concentrations in the top $2 \mathrm{~cm}$ of snow $\left(\left[\mathrm{NO}_{3}^{-}\right]_{\text {top }}\right)$ in Antarctica are calculated by enhancing $\left[\mathrm{NO}_{3}^{-}\right]_{\text {bot }}$ by a factor of 6 in the top $2 \mathrm{~cm}$ of snow, which is the median of observed $\mathrm{NO}_{3}^{-}$enhancement factors (EF) in Antarctica (Dibb et al., 2004; Erbland et al., 2013; Frey et al., 2009; Mayewski and Legrand, 1990; Rothlisberger et al., 2000). Since $\mathrm{NO}_{3}^{-}$concentrations in Antarctica are enhanced by a factor of 6 in the top $2 \mathrm{~cm}$ of snow, an equal amount of $\mathrm{NO}_{3}^{-}$has been removed from the remainder of the photic zone depth to maintain mass balance of $\mathrm{NO}_{3}^{-}$within the snow column. In the modeled Greenland snowpack, $\left[\mathrm{NO}_{3}^{-}\right]_{\text {top }}$ is not enhanced $(\mathrm{EF}=1)$ although $\mathrm{EF}$ is varied in a sensitivity study to assess the impact of EF on snow-sourced $\mathrm{NO}_{x}$ in Greenland (Sect. 3.7).

As mentioned in the introduction, the measured quantum yields for the dominant $\mathrm{NO}_{3}^{-}$photolysis pathway (Eq. 1) range from 0.003 molec photon $^{-1}$ (Chu and Anastasio, 2003) to 0.6 molec photon $^{-1}$ (Zhu et al., 2010) at $T=253 \mathrm{~K}$ and exhibit a dependency on temperature (see temperaturedependent equation in Chu and Anastasio, 2003). A higher fraction of $\mathrm{NO}_{3}^{-}$was likely present on ice surfaces in the Zhu et al. (2010) study compared to the Chu and Anas- tasio (2003) study due to the different sample preparation methods, and likely explains the 3 order-of-magnitude difference in quantum yields. This interpretation suggests $\mathrm{NO}_{3}^{-}$ on the surface of ice grains is much more photolabile compared to $\mathrm{NO}_{3}^{-}$embedded within ice grains, consistent with results from Meusinger et al. (2014). In this study, we assume that buried $\mathrm{NO}_{3}^{-}$, i.e., wet deposited to the snow surface, is more likely to be embedded in the interior of a snow grain compared to $\mathrm{NO}_{3}^{-}$that is dry deposited to the surface of the snow grain. To simulate this effect in an idealized snowpack, we do not adjust the quantum yields, but instead scale snow $\mathrm{NO}_{3}^{-}$concentrations by the fraction of dry relative to total (wet + dry) deposition to the Antarctic and Greenland snow surface, assuming that only the fraction of dry deposited $\mathrm{NO}_{3}^{-}$is photolabile $\left(F_{\mathrm{p}}\right)$. The degree of migration of $\mathrm{NO}_{3}^{-}$ within a snow grain after deposition due to snow metamorphism is unknown, which may influence the photolability of $\mathrm{NO}_{3}^{-}$(Domine and Shepson, 2002).

Other modeling studies have attempted to calculate the fraction of photolabile $\mathrm{NO}_{3}^{-}$in snow by estimating the concentration of $\mathrm{NO}_{3}^{-}$contained within the LLR on the surface of ice grains (e.g., Thomas et al., 2012). In this work, we do not explicitly calculate $\mathrm{NO}_{3}^{-}$photolysis within the LLR because there are still many unknowns about the LLR (Domine et al., 2013), including the distribution of $\mathrm{NO}_{3}^{-}$between the bulk snow and the LLR. This distribution is better understood for some species, such as chloride (Cho et al., 2002), but it is unclear if $\mathrm{NO}_{3}^{-}$behaves similarly. In this study, we have assumed that all $\mathrm{NO}_{x}$ formed from the photolysis of photolabile $\mathrm{NO}_{3}^{-}$is transferred to the boundary layer, which neglects any recombination chemistry (e.g., Erbland et al., 2015) that prevents $\mathrm{NO}_{x}$ from leaving the ice matrix, and may lead to overestimates in the modeled $F_{\mathrm{NO}_{x}}$ values presented in this study. The quantum yield for $\mathrm{NO}_{3}^{-}$photolysis is dependent on the location of $\mathrm{NO}_{3}^{-}$in snow, and although there are uncertainties surrounding the location of $\mathrm{NO}_{3}^{-}$in snow, we perform model sensitivity studies using the full range of measured quantum yields to provide bounds for the amount of $\mathrm{NO}_{x}$ produced from snow $\mathrm{NO}_{3}^{-}$photolysis.

\subsection{Model sensitivity studies}

Model results from Greenland and Antarctica are compared in Sect. 3, which sheds light on the influence of chemical and meteorological parameters on $F_{\mathrm{NO}_{x}}$, nitrogen recycling and redistribution, and $\mathrm{NO}_{3}^{-}$loss from snow. Additionally, due to uncertainties in our understanding of snow photochemistry (Domine et al., 2013), we perform a variety of model sensitivity studies, as shown in Table 3 . The range of values used for the parameters varied in the sensitivity studies reflects our estimates of their uncertainties. The majority of these sensitivity studies focus on Antarctica, but the sensitivity of $F_{\mathrm{NO}_{x}}$ to EF is tested in Greenland. The quantum yield is varied from 0.002 molec photon $^{-1}$ (corresponding to $\mathrm{T}=244 \mathrm{~K})\left(\mathrm{Chu}\right.$ and Anastasio, 2003) to 0.6 molec photon $^{-1}$ 
Table 2. Value(s) of parameters used in the model.

\begin{tabular}{|c|c|c|}
\hline Variable & Value(s) used in model & References \\
\hline$\phi$ & $\begin{array}{l}0.0015-0.0052 \text { molec photon }^{-1} \text { a (Antarctica) } \\
0.0032-0.0069 \text { molec photon }^{-1} \text { a (Greenland) }\end{array}$ & Chu and Anastasio (2003) \\
\hline$\sigma_{\mathrm{NO}_{3}^{-}}$ & $\begin{array}{l}2.7 \times 10^{-20} \mathrm{~cm}^{2}(\lambda=298-307 \mathrm{~nm}) \\
2.4 \times 10^{-20} \mathrm{~cm}^{2}(\lambda=307-312 \mathrm{~nm}) \\
1.9 \times 10^{-20} \mathrm{~cm}^{2}(\lambda=312-320 \mathrm{~nm}) \\
2.3 \times 10^{-21} \mathrm{~cm}^{2}(\lambda=320-345 \mathrm{~nm})\end{array}$ & Sander et al. (2006) \\
\hline$\varepsilon$ & $-47.9 \%$ & Berhanu et al. (2014) \\
\hline$r_{\mathrm{e}}$ & $\begin{array}{l}86.0-235.0 \mu \mathrm{m}^{\mathrm{b}} \text { (Antarctica) } \\
73.0-211.0 \mu \mathrm{m}^{\mathrm{b}} \text { (Greenland) }\end{array}$ & $\begin{array}{l}\text { Carmagnola et al. (2013) } \\
\text { Gallet et al. (2011) }\end{array}$ \\
\hline$\rho_{\text {snow }}$ & $\begin{array}{l}260-360 \mathrm{~kg} \mathrm{~m}^{-3 \mathrm{~b}} \\
235-350 \mathrm{~kg} \mathrm{~m}^{-3 \mathrm{~b}}\end{array}$ & $\begin{array}{l}\text { Gallet et al. (2011) } \\
\text { Carmagnola et al. (2013) }\end{array}$ \\
\hline $\mathrm{EF}$ & $\begin{array}{l}6^{\mathrm{c}}(\text { Antarctica }) \\
1^{\mathrm{c}}(\text { Greenland })\end{array}$ & $\begin{array}{l}\text { Dibb et al. (2004, 2007) } \\
\text { Erbland et al. (2013) } \\
\text { Frey et al. (2009) } \\
\text { Mayewski and Legrand (1990) } \\
\text { Rothlisberger et al. (2000) }\end{array}$ \\
\hline$\left[\mathrm{NO}_{3}^{-}\right]_{\text {bot }}$ & $\begin{array}{l}60 \mathrm{ng} \mathrm{g}^{-1 \mathrm{~d}} \\
132 \mathrm{ngg}^{-1 \mathrm{e}}\end{array}$ & $\begin{array}{l}\text { Bertler et al. (2005) } \\
\text { Burkhart et al. (2009) } \\
\text { Dibb et al. (2007) } \\
\text { Honrath et al. (2002) } \\
\text { Geng et al. (2014b) }\end{array}$ \\
\hline \multicolumn{3}{|c|}{ a Temperature-dependent equation from Chu and Anastasio (2003) used. The modeled temperatures ranged from 237 to } \\
\hline \multicolumn{3}{|c|}{$\begin{array}{l}271 \mathrm{~K} \text { across Antarctica and } 257 \text { to } 280 \mathrm{~K} \text { across Greenland. }{ }^{\mathrm{b}} \text { Vertical profiles of } r_{\mathrm{e}} \text { range from } 86 \mu \mathrm{m} \text { at the snow surface to } \\
332 \mu \mathrm{m} \text { at } 300 \mathrm{~cm} \text { depth in Antarctica and from } 73 \mu \mathrm{m} \text { at the snow surface to } 211 \mu \mathrm{m} \text { at } 300 \mathrm{~cm} \text { depth in Greenland and are } \\
\text { not varied spatially or temporally. Vertical profiles of } \rho_{\text {snow }} \text { range from } 260 \mathrm{~kg} \mathrm{~m}^{-3} \text { at the snow surface to } 360 \mathrm{~kg} \mathrm{~m}^{-3} \text { at } \\
300 \mathrm{~cm} \text { depth in Antarctica and from } 235 \mathrm{~kg} \mathrm{~m}^{-3} \text { at the snow surface to } 350 \mathrm{~kg} \mathrm{~m}^{-3} \text { at } 300 \mathrm{~cm} \text { depth in Greenland and are } \\
\text { not varied spatially or temporally. Observations from Gallet et al. (2011) (Dome C) are used across Antarctica and from } \\
\text { Carmagnola et al. (2013) (Summit) are used across Greenland. The deepest observed } r_{\mathrm{e}} \text { and } \rho_{\text {snow values are used for all }} \\
\text { modeled } r_{\mathrm{e}} \text { and } \rho_{\text {snow }} \text { values at deeper snow depths. }{ }^{\mathrm{c}} \text { Median of observed } \mathrm{NO}_{3}^{-} \text {enhancement factors in Antarctica (1-17) } \\
\text { and low end of observed } \mathrm{NO}_{3}^{-} \text {enhancement factors in Greenland (1-2). }{ }^{\mathrm{d}} \mathrm{Median}_{\text {of }} \text { observed sub-surface snow } \mathrm{NO}_{3}^{-} \\
\text {mixing ratios from the ITASE campaign (Bertler et al., 2005). }{ }^{\mathrm{e}} \text { Average } \mathrm{NO}_{3}^{-} \text {concentrations from buried snow layer } \\
\text { presented in Table } 3 \text { are used. }\end{array}$} \\
\hline
\end{tabular}

(Zhu et al., 2010). Snow $\mathrm{NO}_{3}^{-}$concentrations below $2 \mathrm{~cm}$ $\left(\left[\mathrm{NO}_{3}^{-}\right]_{\text {bot }}\right)$ are halved and doubled with respect to the basecase scenario and the impact of scaling $\mathrm{NO}_{3}^{-}$concentrations by the fraction of photolabile $\mathrm{NO}_{3}^{-}\left(F_{\mathrm{p}}\right)$ is investigated. The $\mathrm{NO}_{3}^{-}$enhancement factor in the top $2 \mathrm{~cm}$ of snowpack is varied from 1 to 10 , based upon the range of reported observations (Dibb et al., 2004; Frey et al., 2009; Mayewski and Legrand, 1990; Rothlisberger et al., 2000). $C_{\mathrm{BC}}$ is halved and doubled with respect to the base-case scenario. Since field and satellite measurements suggest significant increases in surface $r_{\mathrm{e}}$ throughout austral summer in Antarctica (Jin et al., 2008; Klein, 2014), the impact of increasing surface $r_{\mathrm{e}}$ during austral summer on $F_{\mathrm{NO}_{x}}$ in Antarctica is evaluated in this study. The $r_{\mathrm{e}}$ profiles are varied in three sensitivity studies to examine its influence on $F_{\mathrm{NO}_{x}}$. The bulk extinction coefficient for snow ( Kext $\left._{\text {tot }}\right)$ is increased and decreased by $20 \%$ with respect to the base-case scenario because Libois et al. (2013) suggest that the spherical snow grain assumption overestimates $e$-folding depths by a factor of 1.2. These sensitivity studies are used to provide estimates of the influence the uncertainty in these parameters on calculations of $F_{\mathrm{NO}_{x}}$.

\subsection{Estimating the impact of snow $\mathrm{NO}_{3}^{-}$photolysis on boundary layer chemistry and ice-core $\mathrm{NO}_{3}^{-}$ records}

$\mathrm{NO}_{3}^{-}$photolysis, followed by oxidation, recycling, and redistribution of snow-sourced reactive nitrogen, influences both boundary layer chemistry and the concentration and isotopic signature of $\mathrm{NO}_{3}^{-}$that is ultimately preserved in ice-core records. The preservation of $\mathrm{NO}_{3}^{-}$in ice cores is most dependent on the amount of $\mathrm{NO}_{3}^{-}$lost from the snow through photolysis via transport of snow-sourced $\mathrm{NO}_{x}$ away from the site of primary deposition. The methods used to explore 
and quantify nitrogen recycling and photolysis-driven loss of $\mathrm{NO}_{3}^{-}$in snow are described in the following sections.

\subsubsection{Reactive nitrogen recycling between the air and snow}

The nitrogen recycling factor (NRF) is a metric originally proposed by Davis et al. (2008) to quantify the degree of reactive nitrogen recycling in snow over 1 year. The NRF is calculated in Eq. (9):

$\mathrm{NRF}=\frac{F_{\mathrm{NO}_{x}}}{F_{\mathrm{PRI}}}$.

In Eq. (9), $F_{\mathrm{NO}_{x}}\left(\mathrm{ng} \mathrm{N} \mathrm{m}^{-2} \mathrm{yr}^{-1}\right)$ is the annual sum of $\mathrm{NO}_{x}$ released from the snow and $F_{\mathrm{PRI}}\left(\mathrm{ng} \mathrm{N} \mathrm{m}^{-2} \mathrm{yr}^{-1}\right)$ is the annual sum of primary $\mathrm{NO}_{3}^{-}$deposited to the snow. Davis et al. (2008) use the NRF to describe nitrogen recycling on both macro-scale (e.g., across the East Antarctic plateau) and micro-scale (e.g., the number of times one molecule of $\mathrm{NO}_{3}^{-}$ is recycled) levels. An NRF greater than 1 suggests that multiple nitrogen recycling events occur in the snow. NRF represents the average, or "bulk" degree of nitrogen recycling in snow because it does not resolve the degree of nitrogen recycling on a molecular level in the snow; some $\mathrm{NO}_{3}^{-}$molecules may never be photolyzed while other $\mathrm{NO}_{3}^{-}$molecules may be photolyzed and recycled many times greater than NRF. The NRF has implications for boundary layer chemistry because the continual re-emission of $\mathrm{NO}_{x}$ enhances the effective concentration of $\mathrm{NO}_{x}$ in the boundary layer (Davis et al., 2008). Additionally, nitrogen recycling between the air and snow may alter the preservation of $\mathrm{NO}_{3}^{-}$in ice-core records.

\subsubsection{Export of snow-sourced $\mathrm{NO}_{3}^{-}$away from the original site of photolysis}

Once snow-sourced $\mathrm{NO}_{x}$ is emitted to the atmosphere, it is subject to transport away from the original site of photolysis. If snow-sourced $\mathrm{NO}_{x}$ is oxidized to $\mathrm{HNO}_{3}$ and re-deposited back to the snow surface, then there is no net photolysisdriven loss of $\mathrm{NO}_{3}^{-}$from the snow. However, if some of the snow-sourced $\mathrm{NO}_{x}$ is transported away from the site of primary deposition, there is a net photolysis-driven loss of $\mathrm{NO}_{3}^{-}$from the snow. The fraction $(f)$ of total $\mathrm{NO}_{3}^{-}$(photolabile + non-photolabile) lost from the snow driven by photolysis is calculated in Eq. (10):

$f=\left(\left(\frac{F_{\mathrm{R}}}{F_{\mathrm{NO}_{x}}}\right)^{\tau_{\mathrm{NO}_{3}^{-}}^{-} \text {burial }}-1\right) \times F_{\mathrm{P}} \times F_{\mathrm{P}_{\text {photo }}}$.

In Eq. (10), negative values of $f$ represent a loss of $\mathrm{NO}_{3}^{-}$ from the snow and positive values of $f$ represent a gain of $\mathrm{NO}_{3}^{-}$to the snow. In Eq. (10), $F_{\mathrm{R}}\left(\mathrm{ng} \mathrm{N} \mathrm{m}^{-2} \mathrm{yr}^{-1}\right)$ is the total annual flux of recycled $\mathrm{NO}_{3}^{-}$to the snow surface and $F_{\mathrm{NO}_{x}}$ ( $\mathrm{ng} \mathrm{N} \mathrm{m}^{-2} \mathrm{yr}^{-1}$ ) is the total annual flux of $\mathrm{NO}_{x}$ released from the snow from photolysis of snow $\mathrm{NO}_{3}^{-}, F_{\mathrm{R}}$ is calculated by subtracting the depositional flux of $\mathrm{NO}_{3}^{-}$from a model run without snow photochemistry from the depositional flux of $\mathrm{NO}_{3}^{-}$from a model run with snow photochemistry. The ratio of $F_{\mathrm{R}}$ to $F_{\mathrm{NO}_{x}}$ represents the fraction of photolabile $\mathrm{NO}_{3}^{-}$remaining in the snow after 1 year. As long as $\mathrm{NO}_{3}^{-}$remains in the photic zone, $\mathrm{NO}_{3}^{-}$can continually be lost from the snow by photolysis-driven processes. The preservation of $\mathrm{NO}_{3}^{-}$in ice cores is dependent on the fraction of $\mathrm{NO}_{3}^{-}$lost from the snow through photolysis during the entire time that $\mathrm{NO}_{3}^{-}$remains in the photic zone. Provided that there are no major changes in parameters that influence snow photochemistry (e.g., LAI, overhead ozone abundance) from year to year, the fraction of photolabile $\mathrm{NO}_{3}^{-}$lost from the snow will be stable from year to year.

$\tau_{\mathrm{NO}_{3}^{-} \text {burial }}$ represents the time that $\mathrm{NO}_{3}^{-}$remains in the photic zone (years), and in Eq. (10), $\tau_{\mathrm{NO}_{3}^{-} \text {burial }}$ accounts for the loss of $\mathrm{NO}_{3}^{-}$that occurs during the entire time that it remains in the photic zone. When $\mathrm{NO}_{3}^{-}$remains in the photic zone for less than a year $\left(\tau_{\mathrm{NO}_{3}^{-} \text {burial }}<1\right), \tau_{\mathrm{NO}_{3}^{-} \text {burial }}$ in Eq. (10) is set equal to $1 . \tau_{\mathrm{NO}_{3}^{-} \text {burial }}$ is calculated according to Eq. (11), where both the depth of the photic zone $(\mathrm{cm})$ and the total annual snow accumulation $\left(\alpha_{\mathrm{r}}\right)\left(\mathrm{cm} \mathrm{yr}^{-1}\right)$ are considered.

$\tau_{\mathrm{NO}_{3 \text { burial }}^{-}}=\frac{z_{\mathrm{e}}}{\alpha_{\mathrm{r}}}$

In Eq. (11), $z_{\mathrm{e}}(\mathrm{cm})$ is $1 e$-folding depth of UV actinic flux and is used instead of $z_{3 \mathrm{e}}$ because 87-91\% of snow-sourced $\mathrm{NO}_{x}$ is produced within the top $1 e$-folding depth. To convert total annual snow accumulation rate from $\mathrm{kg} \mathrm{m}^{-2} \mathrm{yr}^{-1}$ to $\mathrm{cm}$, a typical polar snow density $\left(0.36 \mathrm{~g} \mathrm{~cm}^{-3}\right)$ (Grenfell et al., 1994) is assumed. $\tau_{\mathrm{NO}_{3}^{-} \text {burial }}$ is the minimum amount of time on average that $\mathrm{NO}_{3}^{-}$remains in the top one-third of the snow photic zone before burial beneath because nitrogen recycling, which effectively redistributes $\mathrm{NO}_{3}^{-}$upwards in the snow, is not factored into Eq. (11). $\tau_{\mathrm{NO}_{3}^{-} \text {burial }}$ thus represents the lifetime of $\mathrm{NO}_{3}^{-}$in snow in an average sense and does not resolve photolysis and recycling of individual $\mathrm{NO}_{3}^{-}$ molecules.

In Eq. (10), $\left(\left(\frac{F_{\mathrm{R}}}{F_{\mathrm{NO}}}\right)^{\tau} \mathrm{NO}_{3}^{-}\right.$burial -1$)$ represents the fraction of photolabile $\mathrm{NO}_{3}^{-}$lost from the snow through photolysis. This fraction is multiplied by $F_{\mathrm{p}}$ to calculate the fraction of total (photolabile + non-photolabile) $\mathrm{NO}_{3}^{-}$lost from the snow through photolysis $(f)$. If the lifetime of $\mathrm{NO}_{3}^{-}$against burial is shorter than the lifetime of $\mathrm{NO}_{3}^{-}$against photolysis, $F_{\mathrm{p}}$ is multiplied by $F_{\mathrm{p}_{\text {photo }}}$, which represents the fraction of photolabile $\mathrm{NO}_{3}^{-}$that is buried below the snow photic zone before photolysis. $F_{\mathrm{p}_{\text {photo }}}$ is calculated in Eq. (12):

$$
F_{\mathrm{p}_{\text {photo }}}=\frac{\tau_{\mathrm{NO}_{3 \text { burial }}^{-}}}{\tau_{\mathrm{NO}_{3 \text { photolysis }}^{-}}},
$$


where $\tau_{\mathrm{NO}_{3}^{-} \text {burial }}$ represents the lifetime of $\mathrm{NO}_{3}^{-}$against burial below the photic zone and $\tau_{\mathrm{NO}_{3}^{-} \text {photolysis }}$ is lifetime of $\mathrm{NO}_{3}^{-}$ against photolysis. $\tau_{\mathrm{NO}_{3}^{-} \text {photolysis }}$ is calculated in Eq. (13):

$\tau_{\mathrm{NO}_{3 \text { photolysis }}^{-}}=\frac{1}{J}$.

In Eq. (13), $J$ (Eq. 8) has been integrated from $\lambda=298$ $345 \mathrm{~nm}$ and averaged over the top $e$-folding depth in snow $\left(z_{\mathrm{e}}\right) \cdot \tau_{\mathrm{NO}_{3}^{-} \text {photolysis }}$ represents the average lifetime of $\mathrm{NO}_{3}^{-}$in the snow photic zone against loss by photolysis.

If $f$ is 0 , then all snow-sourced $\mathrm{NO}_{x}$ is redeposited to the snow and there is no net loss of $\mathrm{NO}_{3}^{-} \cdot f$ is also 0 if the net export of snow-sourced $\mathrm{NO}_{x}$ away from the site of original photolysis is balanced by net import of snow-sourced $\mathrm{NO}_{x}$ from other Antarctic or Greenland locations. If $-1 \leq f \leq 0$, the export of local snow-sourced $\mathrm{NO}_{x}$ is higher than the deposition of snow-sourced $\mathrm{NO}_{x}$ from elsewhere in Antarctica or Greenland, resulting in net photolysis-driven loss of $\mathrm{NO}_{3}^{-}$from the snow. If $f>0$, the export of local snowsourced $\mathrm{NO}_{x}$ is lower than the deposition of snow-sourced $\mathrm{NO}_{x}$ from elsewhere in Antarctica or Greenland, resulting in net photolysis-driven gain of $\mathrm{NO}_{3}^{-}$to the snow.

$f$ is used to calculate the enrichment in ice-core $\delta^{15} \mathrm{~N}\left(\mathrm{NO}_{3}^{-}\right)$due solely to the impact of photolysis-driven loss of $\mathrm{NO}_{3}^{-}$in snow when $-1 \leq f<0$. We use a Rayleigh fractionation equation to calculate $\delta^{15} \mathrm{~N}\left(\mathrm{NO}_{3}^{-}\right)$(Blunier et al., 2005):

$\delta^{15} N\left(\mathrm{NO}_{3}^{-}\right)=\left(\left(\delta^{15} N\left(\mathrm{NO}_{3}^{-}\right)_{\mathrm{air}}+1\right)(1+f)^{\varepsilon}\right)-1$.

In Eq. (14), $\delta^{15} N\left(\mathrm{NO}_{3}^{-}\right)_{\text {air }}$ is the annual-averaged $\delta^{15} \mathrm{~N}$ value of boundary layer $\mathrm{NO}_{3}^{-}$and $\varepsilon$ is the fractionation constant (-47.9\%o; Berhanu et al., 2014). In this work, we set $\delta^{15} N\left(\mathrm{NO}_{3}^{-}\right)_{\text {air }}$ equal to $0 \%$ o to investigate the enrichment in $\delta^{15} \mathrm{~N}\left(\mathrm{NO}_{3}^{-}\right)$only from photolysis-driven loss of $\mathrm{NO}_{3}^{-}$from snow. The model-calculated $\delta^{15} \mathrm{~N}\left(\mathrm{NO}_{3}^{-}\right)$enrichments represent values in snow below the photic zone (i.e., at depths where sunlight is minimal and $\mathrm{NO}_{3}^{-}$photolysis is not occurring) because these values are indicative of the loss of snow $\mathrm{NO}_{3}^{-}$over the total time that it spent in the snow photic zone. When $\mathrm{NO}_{3}^{-}$is buried below the snow photic zone, no more photolysis or alteration of $\delta^{15} \mathrm{~N}\left(\mathrm{NO}_{3}^{-}\right)$occurs; hence, the $\delta^{15} \mathrm{~N}\left(\mathrm{NO}_{3}^{-}\right)$is further unaltered and is preserved in the icecore record. The chemical and physical properties of snow within the photic zone are used to estimate what the enrichment in $\delta^{15} \mathrm{~N}\left(\mathrm{NO}_{3}^{-}\right)$would be in ice cores at depths below the snow photic zone.
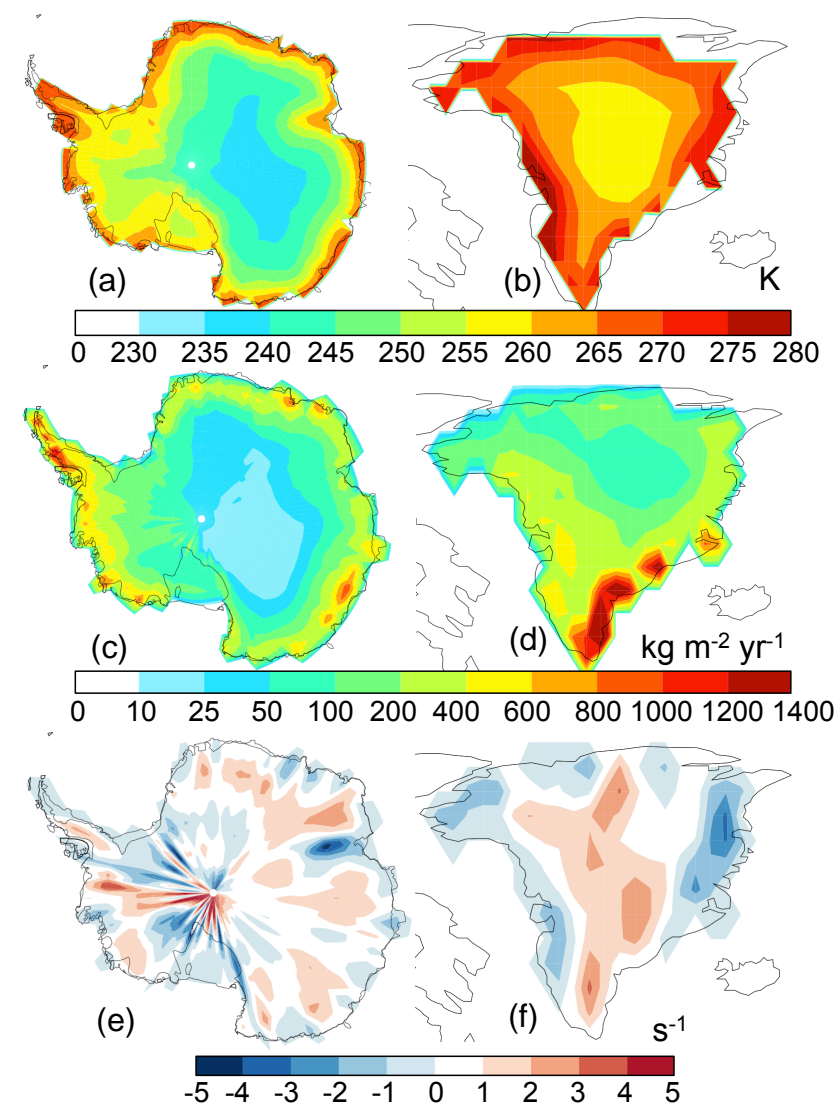

Figure 2. Modeled meteorological variables in GEOS-Chem. (a, b) Mean summer (DJF, Antarctica; JJA, Greenland) air temperature in lowest vertical grid box. (c, d) Annual total snow accumulation rate $\left(\mathrm{kg} \mathrm{m}^{-2} \mathrm{yr}^{-1}\right)$ from May 2009 to May 2010. (e, f) Annual mean surface wind divergence $\left(s^{-1}\right)$ from May 2009 to May 2010. Blue regions indicate regions of convergence.

\section{Results and discussion}

\subsection{Parameters that influence $\boldsymbol{F}_{\mathrm{NO}_{x}}$ and its spatial redistribution}

Figure $2 \mathrm{a}$ and $\mathrm{b}$ present modeled air temperature in the lowest vertical grid boxes, which range from 237 to $271 \mathrm{~K}$ in Antarctica and 257 to $280 \mathrm{~K}$ in Greenland; lowest temperatures are located at the highest elevations. Figure $2 \mathrm{c}$ and $\mathrm{d}$ show modeled total annual snow accumulation rates from GEOSChem $\left(\mathrm{kg} \mathrm{m}^{-2} \mathrm{yr}^{-1}\right)$, ranging from 10 to $700 \mathrm{~kg} \mathrm{~m}^{-2} \mathrm{yr}^{-1}$ in Antarctica and 60 to $1400 \mathrm{~kg} \mathrm{~m}^{-2} \mathrm{yr}^{-1}$ in Greenland. In both regions, the decrease in snow accumulation rate from the coast to the top of the plateau is attributed to increased distance from the ocean (moisture source), increased elevation, and lower temperatures. Figure $2 \mathrm{e}$ and $\mathrm{f}$ show modeled annual mean surface wind divergence from May 2009 to May 2010. Figure 2e is consistent with Antarctic Mesoscale Prediction System surface wind output (Fig. 3 in Parish and Bromwich, 2007), indicating that the large-scale airflow 


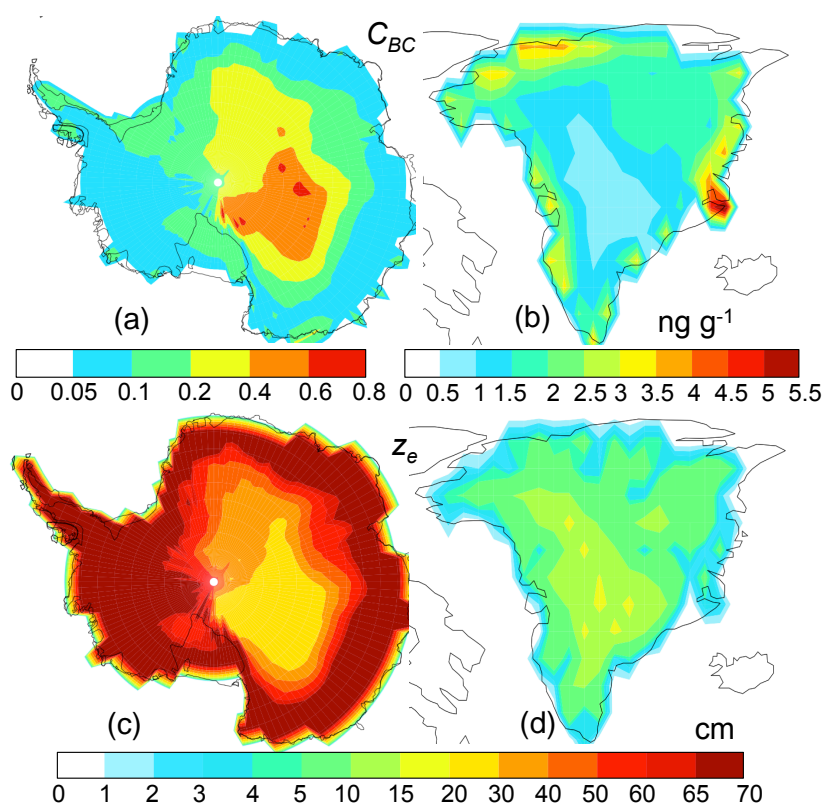

Figure 3. (a, b) Modeled annual mean snow black carbon concentrations $\left(C_{\mathrm{BC}}\right)$. (c, d) Calculated mean summer (DJF, Antarctica; JJA, Greenland) UV $e$-folding depth $\left(z_{\mathrm{e}}\right)$.

pattern in Antarctica flows from the East Antarctic plateau downslope towards the coast (katabatic winds). There are three major regions of wind convergence in Antarctica, located near the Ross, Ronne, and Amery ice shelves. In Greenland, air generally flows downwards from the continental interior towards the coasts.

Figure $3 \mathrm{a}$ and $\mathrm{b}$ present modeled snow $C_{\mathrm{BC}}$, ranging from 0.08 to $0.6 \mathrm{ng} \mathrm{g}^{-1}$ in Antarctica and 0.8 to $5.5 \mathrm{ng} \mathrm{g}^{-1}$ in Greenland. In Antarctica, the highest $C_{\mathrm{BC}}$ values are found on the East Antarctic plateau and the spatial pattern of $C_{\mathrm{BC}}$ is governed by the snow accumulation rate; higher snow accumulation rates dilute $C_{\mathrm{BC}}$ (Doherty et al., 2013). The modeled boundary layer black carbon concentrations are relatively uniform across Antarctica (0.1-0.6 pptv) because the majority of black carbon reaches Antarctica through longrange transport (with the exception of local production from Antarctic research stations). In Greenland, the highest $C_{\mathrm{BC}}$ values are found at the coasts due to their proximity to pollution sources, even though snow accumulation rates are highest at the coasts as well. Figure $3 \mathrm{c}$ and $\mathrm{d}$ show mean summer (DJF, Antarctica; JJA, Greenland) $e$-folding depths of UV actinic flux in snow $\left(z_{\mathrm{e}}\right)$, which range from 24 to $69 \mathrm{~cm}$ in Antarctica and 2 to $17 \mathrm{~cm}$ in Greenland. The shallowest $e$ folding depths are located in regions of relatively high $C_{\mathrm{BC}}$, which is on the plateau in Antarctica and at the coasts in Greenland. Higher $C_{\mathrm{BC}}$ in snow results in shallower $z_{\mathrm{e}}$ because UV absorption in snow is enhanced as the concentration of LAIs increases (Zatko et al., 2013). In this study, coastal grid boxes are a mixture of water, sea ice, and snowcovered surfaces, and since actinic flux profiles are only cal-
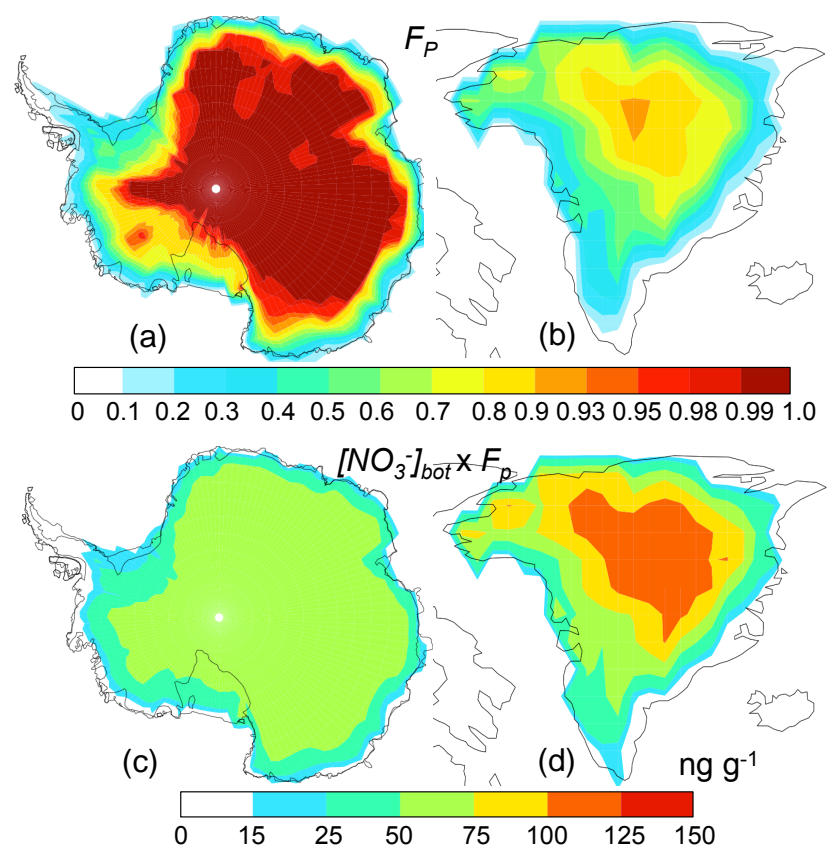

Figure 4. (a, b) Ratio of annual dry-deposited $\mathrm{NO}_{3}^{-}$to annual total deposited $\mathrm{NO}_{3}^{-}, F_{\mathrm{P}}$. (c, d) Annual sub-surface snow $\mathrm{NO}_{3}^{-}$concentrations $\left(\left[\mathrm{NO}_{3}^{-}\right]_{\text {bot }} \times F_{\mathrm{p}}\right)$ used in the model.

culated for snow-covered surfaces, the average $z_{\mathrm{e}}$ in coastal grid boxes are artificially shallow.

Figure $4 \mathrm{a}$ and $\mathrm{b}$ show the fraction of dry-deposited $\mathrm{NO}_{3}^{-}$ compared to total deposited $\mathrm{NO}_{3}^{-}$across Antarctica and Greenland. The ratio of dry deposition to total deposition ranges from 0.05 in coastal Antarctica and coastal Greenland to 0.92 in central Greenland and 0.99 on the East Antarctic plateau. Figure $4 \mathrm{c}$ and d show annual mean sub-surface (from $2 \mathrm{~cm}$ depth to the bottom of the photic zone, $z_{3 \mathrm{e}}$ ) snow $\mathrm{NO}_{3}^{-}$concentrations ( $\left.\left[\mathrm{NO}_{3}^{-}\right]_{\text {bot }}\right)$ in the model scaled by $F_{\mathrm{p}}$, $\left(\left[\mathrm{NO}_{3}^{-}\right]_{\text {bot }} \times F_{\mathrm{p}}\right)$, which ranges from 13 to $60 \mathrm{ng} \mathrm{g}^{-1}$ across Antarctica and 8 to $121 \mathrm{ng} \mathrm{g}^{-1}$ across Greenland.

\subsection{Emission, recycling, and redistribution of nitrogen across Antarctica and Greenland}

Figure 5 shows model-calculated mean summer snowsourced $\mathrm{NO}_{x}$ flux, $\overline{F_{\mathrm{NO}_{x}}}$, across Antarctica and Greenland. The spatial patterns of $\overline{F_{\mathrm{NO}_{x}}}$ in Fig. 5 are governed by the depth of the photic zone $\left(z_{\mathrm{e}}\right)$ (especially in Antarctica) and also the concentration of photolabile $\mathrm{NO}_{3}^{-}$(Fig. $4 \mathrm{a}$ and b), which is lowest at the coasts in both Antarctica and Greenland in the model. Additionally, spatial patterns of $\overline{F_{\mathrm{NO}_{x}}}$ are influenced by the temperature-dependent quantum yield; the highest quantum yield values are located at the coasts where temperatures are highest. $\overline{F_{\mathrm{NO}_{x}}}$ ranges from 0.01-6.4 $\times 10^{8}$ molec cm $\mathrm{cm}^{-2} \mathrm{~s}^{-1}$ in Antarctica and 0.5$11 \times 10^{8}$ molec cm $\mathrm{cm}^{-2} \mathrm{~s}^{-1}$ in Greenland. 


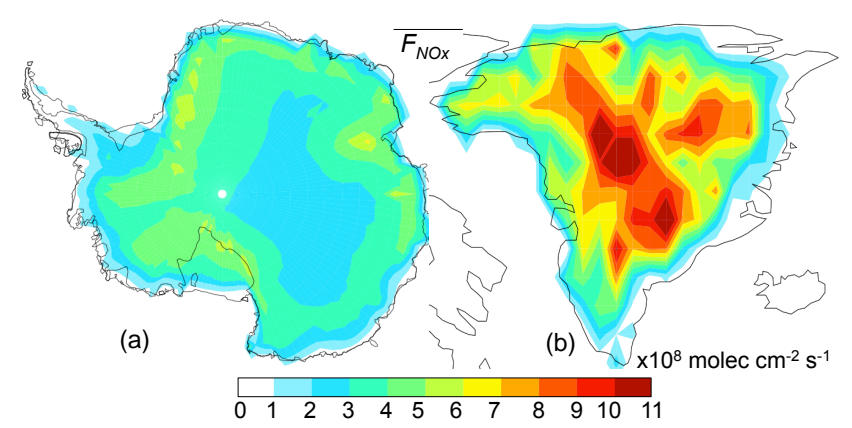

Figure 5. Mean summer (DJF, Antarctica; JJA, Greenland) flux of snow-sourced $\mathrm{NO}_{x}$ from the snow $\left(\overline{F_{\mathrm{NO}_{x}}}\right)$.

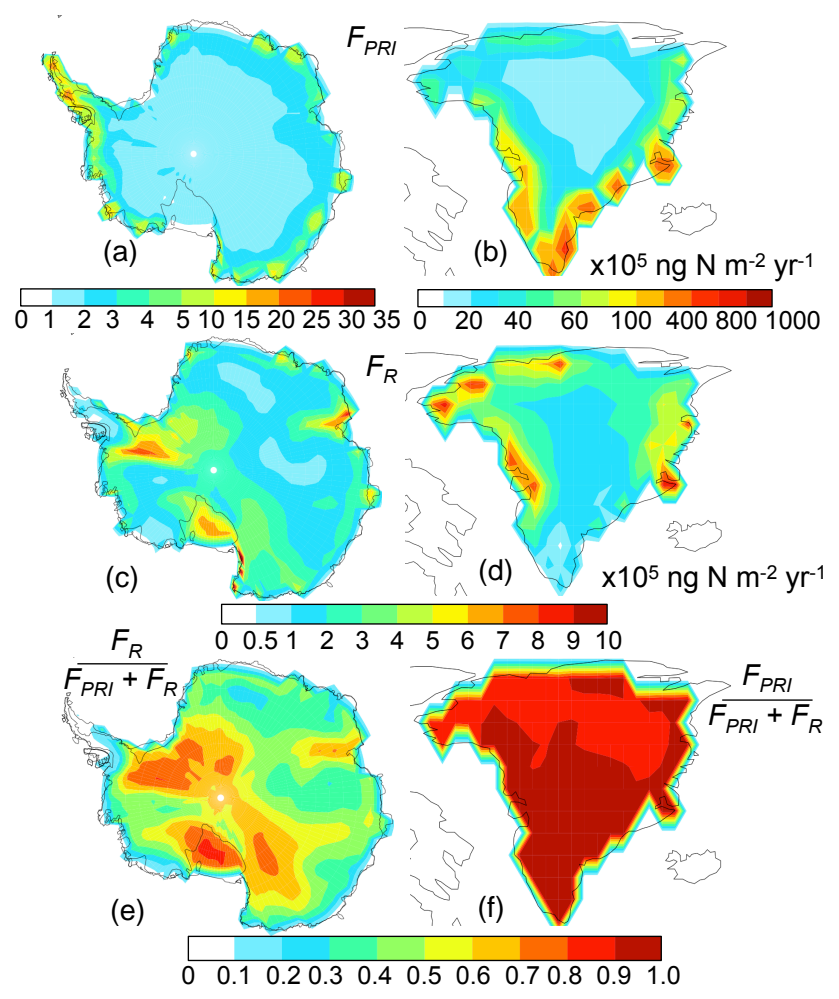

Figure 6. (a, b) Annual wet plus dry deposition flux of primary $\mathrm{NO}_{3}^{-}$to the snow $\left(F_{\mathrm{PRI}}\right)$. (c, d) Annual wet plus dry deposition flux of recycled $\mathrm{NO}_{3}^{-}$to the snow $\left(F_{\mathrm{R}}\right)$. (e) Ratio of $F_{\mathrm{R}}$ to the total downward $\mathrm{NO}_{3}^{-}$flux $\left(\frac{F_{\mathrm{R}}}{F_{\mathrm{PRI}}+F_{\mathrm{R}}}\right)$ for the base-case scenario. (f) Ratio of $F_{\mathrm{PRI}}$ to the total downward $\mathrm{NO}_{3}^{-}$flux $\left(\frac{F_{\mathrm{PRI}}}{F_{\mathrm{PRI}}+F_{\mathrm{R}}}\right)$.

Figure $6 \mathrm{a}$ and $\mathrm{b}$ present the total annual depositional flux of primary $\mathrm{NO}_{3}^{-}\left(F_{\mathrm{PRI}}\right)$, which ranges from $0.9-35 \times 10^{5} \mathrm{ng} \mathrm{N} \mathrm{m}^{-2} \mathrm{yr}^{-1}$ in Antarctica and $14-1000 \times$ $10^{5} \mathrm{ng} \mathrm{N} \mathrm{m}^{-2} \mathrm{yr}^{-1}$ in Greenland and is highest at the coasts due to its relative proximity to $\mathrm{NO}_{x}$-source regions in lower latitudes. An adjoint modeling study by Lee et al. (2014) suggests that boundary layer $\mathrm{NO}_{3}^{-}$abundance in Antarctica is dominated by $\mathrm{NO}_{3}^{-}$transport to Antarctica originating from $\mathrm{NO}_{x}$ emissions from 25 to $65^{\circ} \mathrm{S}$ during austral winter and

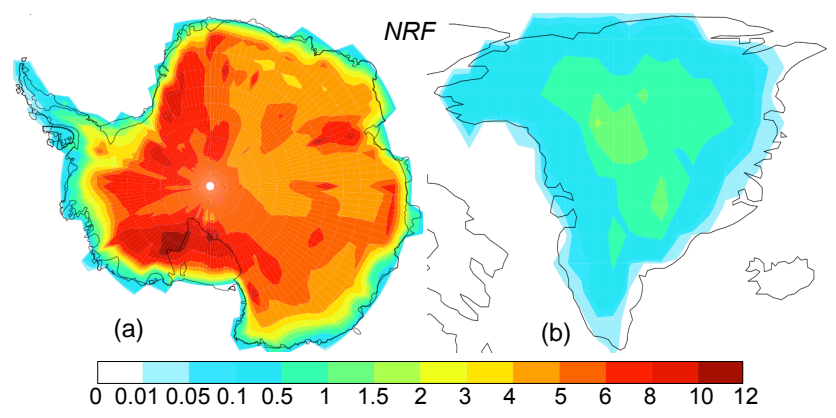

Figure 7. Nitrogen recycling factor (NRF; Eq. 9).

by thermal decomposition of peroxyacyl nitrate (PAN) as it descends from the free troposphere in all other seasons. In Greenland, boundary layer nitrate is predominately in the gas phase $\left(\mathrm{HNO}_{3}\right)$ (Bergin et al., 1995; Dibb et al., 1994) and it has been suggested that $\mathrm{NO}_{3}^{-}$in Greenland snow originates from both the troposphere (Geng et al., 2014a; Wespes et al., 2012) and stratosphere (Davidson et al., 1989).

Figure $6 \mathrm{c}$ and $\mathrm{d}$ show the total annual depositional flux of recycled $\mathrm{NO}_{3}^{-}\left(F_{\mathrm{R}}\right)$, which ranges from $0.5-11 \times 10^{5} \mathrm{ng} \mathrm{N} \mathrm{m}^{-2} \mathrm{yr}^{-1}$ in Antarctica and $0.4-9 \times$ $10^{5} \mathrm{ng} \mathrm{N} \mathrm{m}^{-2} \mathrm{yr}^{-1}$ in Greenland and is highest in areas of wind convergence (Greenland coasts and Antarctic ice shelves). Figure 6e shows the ratio of deposition of recycled nitrogen $\left(F_{\mathrm{R}}\right)$ to total deposition $\left(F_{\mathrm{PRI}}+F_{\mathrm{R}}\right)$ in Antarctica. In Antarctica, recycled nitrogen $\left(F_{\mathrm{R}}\right)$ is the dominant $(50-85 \%)$ form of $\mathrm{NO}_{3}^{-}$deposition along the Transantarctic Mountains and in regions of wind convergence, such as the Ronne, Ross, and Amery ice shelves. Along the Antarctic coast, $F_{\mathrm{R}}$ represents as little as $11 \%$ of the deposition flux. Figure $6 f$ shows the ratio of total annual primary $\mathrm{NO}_{3}^{-}$deposition to total $\mathrm{NO}_{3}^{-}$deposition (primary + recycled) in Greenland. Primary $\mathrm{NO}_{3}^{-}$deposition is responsible for at least $85 \%$ of total $\mathrm{NO}_{3}^{-}$deposition across most of Greenland, and up to $100 \%$ in southern Greenland. This ratio is set equal to 0 over the ocean and sea ice, which leads to artificially low ratios at the coast because the model grid boxes at the coasts are an average of ocean, sea ice, and continental values.

Figure 7 shows the NRF, which ranges from 0.2 to 12 across Antarctica and 0.01 to 1.6 across Greenland. Nitrogen is recycled multiple times over the course of 1 year across most of Antarctica, with the exception of the coasts. In contrast, NRF values are less than 1.5 across all of Greenland. The spatial pattern of NRF is governed by the flux of snowsourced $\mathrm{NO}_{x}$, which is influenced by the depth of the photic zone $\left(z_{\mathrm{e}}\right)$, the concentration of photolabile $\mathrm{NO}_{3}^{-}$, and the temperature-dependent quantum yield for $\mathrm{NO}_{3}^{-}$photolysis. The spatial pattern of NRF is also dependent on $F_{\mathrm{PRI}}$, which is highest at the coasts and lowest at the top of the plateaus. In both Antarctica and Greenland, NRF values are lowest near the coast because the fraction of photolabile $\mathrm{NO}_{3}^{-}$is small and $F_{\mathrm{PRI}}$ values are high. The maximum NRF values gener- 
ally occur in regions corresponding to maximum $F_{\mathrm{NO}_{x}}$ values. Our calculated NRF value at Dome $C$ is 6, compared to a value of 4 calculated by Erbland et al. (2015). Davis et al. (2008) estimate an NRF of 1.8, which is roughly 3 to 6 times lower than the modeled East Antarctic NRF values in this study (NRF $=5-10)$, although Davis et al. (2008) state that their estimated NRF value could be factors of 3-5 times higher due to uncertainties in primary nitrogen deposition estimates. Erbland et al. (2015) found a relationship between inverse snow accumulation rates and nitrogen recycling in regions where the snow accumulation rates $\left(\alpha_{\mathrm{r}}\right)$ are higher than $50 \mathrm{~kg} \mathrm{~m}^{-2} \mathrm{a}^{-1}$ in Antarctica. The relationship between NRF and $1 / \alpha_{\mathrm{r}}$ in our model simulations for $\alpha_{\mathrm{r}}>50 \mathrm{~kg} \mathrm{~m}^{-2} \mathrm{a}^{-1}$ in Antarctica suggests that only $22 \%$ of the spatial variability of NRF can be explained by $\alpha_{\mathrm{r}}$ (Fig. S1 in the Supplement), likely due to the redistribution of snow-sourced reactive nitrogen across Antarctica by winds. In Greenland, which is a region where snow accumulation rates are greater than $50 \mathrm{~kg} \mathrm{~m}^{-2} \mathrm{a}^{-1}$, our model simulations suggest that only $30 \%$ of the spatial variability of NRF can be explained by $\alpha_{\mathrm{r}}$ (Fig. S2).

\subsection{Impact of reactive nitrogen recycling on boundary layer chemistry}

The height of the boundary layer will strongly influence the abundance of $\mathrm{NO}_{3}^{-}$, reactive nitrogen oxides, and oxidants emitted or formed at or near the surface. At many polar stations (e.g., Neumayer, South Pole, Dome C, Halley, Kohnen, Summit) there is a wide range of observed boundary layer heights during summer (10-600 m; Casasanta et al., 2014; Cohen et al., 2007; Davis et al., 2004; Drue and Heinemann, 2007; Handorf, 1996; Helmig et al., 2002; Jones et al., 2006, 2008; King et al., 2006; Kodama et al., 1985; Konig-Langlo et al., 1998; Neff et al., 2008; Oncley et al., 2004; Travouillon et al., 2008; Weller et al., 1999), and although modeled boundary layer heights are not systematically biased in one direction compared to observations, they often do not agree well. Therefore, only the relative impacts of snow photochemistry on reactive nitrogen and oxidant abundances are evaluated in this study. The impact of snow $\mathrm{NO}_{3}^{-}$photolysis on boundary layer chemistry can be examined by considering factor changes in boundary layer $\mathrm{NO}_{x}$, total nitrate (gas-plus aerosol-phase), $\mathrm{OH}$, and $\mathrm{O}_{3}$ mixing ratios between simulations with and without snow $\mathrm{NO}_{3}^{-}$photolysis. Other snow photochemical reactions mentioned in the introduction but not included in this modeling study will also impact oxidant abundances, but the effects of each photochemical reaction are not additive due to the highly non-linear nature of oxidant cycling.

As shown in Fig. 8, the inclusion of a snow $\mathrm{NO}_{x}$ source leads to factor increases in boundary layer mixing ratios of $\mathrm{NO}_{x}$ from 1.2 to 24.5, gas-plus aerosol-phase nitrate from 1.0 to $11.8, \mathrm{OH}$ from 1.8 to 5.3 , and $\mathrm{O}_{3}$ from 1.1 to 1.8 in Antarctica. The largest factor increases are in West Antarc-

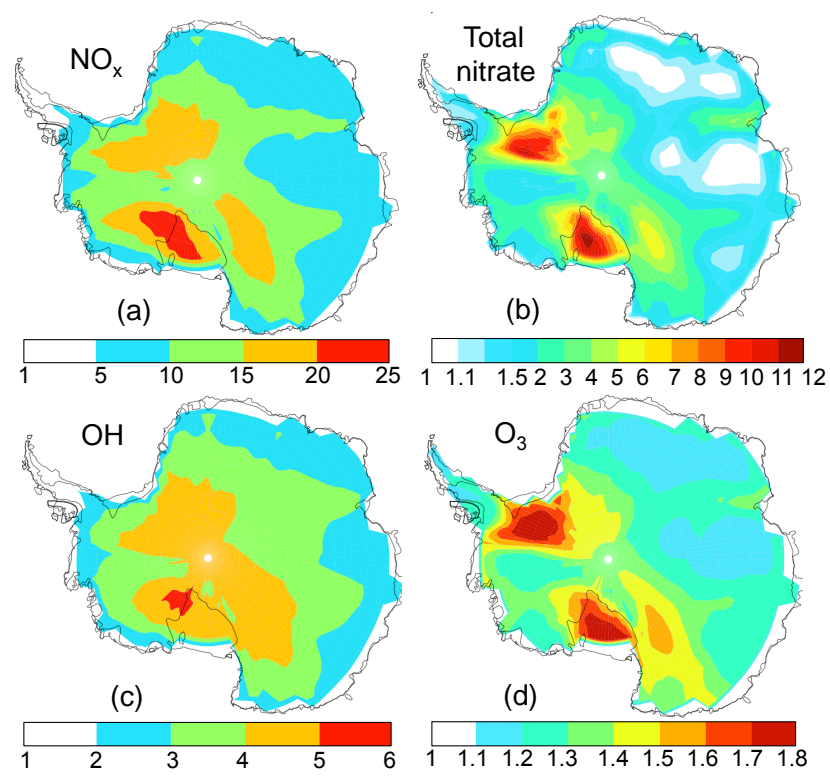

Figure 8. Factor increase in mean austral summer (DJF) boundary layer (a) $\mathrm{NO}_{x}$, (b) gas + aerosol-phase nitrate, (c) $\mathrm{OH}$, and (d) $\mathrm{O}_{3}$ mixing ratios between model runs with $F_{\mathrm{NO}_{x}}$ compared to without $F_{\mathrm{NO}_{x}}$.

tica, particularly near the Ross and Ronne ice shelves, where winds carrying photo-produced species converge. The surface transport pattern is especially important for the redistribution of the longer-lived species $\mathrm{NO}_{3}^{-}$and $\mathrm{O}_{3}$. Figure 9 shows that the inclusion of a snow $\mathrm{NO}_{x}$ source leads to factor increases in boundary layer mixing ratios of $\mathrm{NO}_{x}$ from 1.0 to 6.3 , gas-plus aerosol-phase nitrate from 1.0 to $2.2, \mathrm{OH}$ from 1.1 to 2.4 , and $\mathrm{O}_{3}$ from 1.0 to 1.14 in Greenland. The largest factor increases for short-lived species $\left(\mathrm{NO}_{x}\right.$ and $\left.\mathrm{OH}\right)$ are in central Greenland where $F_{\mathrm{NO}_{x}}$ is highest (Fig. 5), while the largest factor increases for longer-lived species $\left(\mathrm{NO}_{3}^{-}\right.$and $\mathrm{O}_{3}$ ) are located in regions of wind convergence.

\subsection{Implications for ice-core records of $\mathrm{NO}_{3}^{-}$ concentrations and isotopes}

Figure 10a and $\mathrm{b}$ show the minimum amount of time that snow $\mathrm{NO}_{3}^{-}$remains in the photic zone on average, $\tau_{\mathrm{NO}_{3}^{-}}$burial (Eq. 11) as calculated in the model. $\mathrm{NO}_{3}^{-}$remains in the snow photic zone for 4 months near the Antarctic coasts and up to 6.5 years on the East Antarctic plateau before burial below the photic zone. In Greenland, $\mathrm{NO}_{3}^{-}$remains in the photic zone for 0.1 months at the coasts and up to 7 months in central Greenland. The spatial pattern of $\tau_{\mathrm{NO}_{3}^{-} \text {burial }}$ is governed by the snow accumulation rate, both directly and indirectly through its influence on $C_{\mathrm{BC}}$. The spatial patterns of $\tau_{\mathrm{NO}_{3}^{-} \text {burial }}$ are in agreement with the expectation that $\mathrm{NO}_{3}^{-}$remains in the photic zone the longest in areas with low snow accumulation rates. 


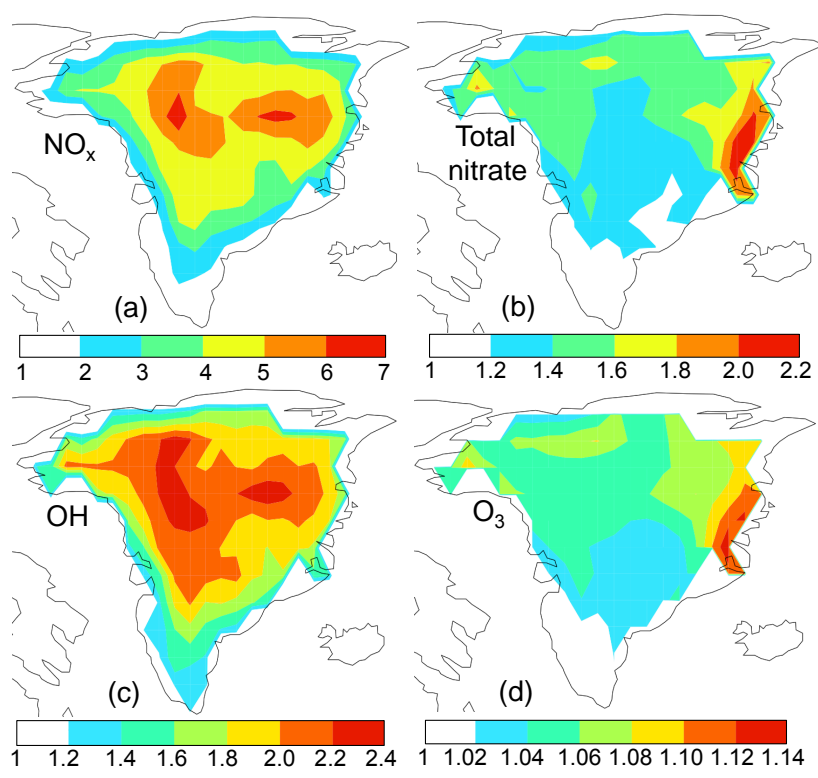

Figure 9. Factor increase in mean summer (JJA) boundary layer (a) $\mathrm{NO}_{x}$, (b) gas + aerosol-phase nitrate, (c) $\mathrm{OH}$, and (d) $\mathrm{O}_{3}$ mixing ratios between model runs with $F_{\mathrm{NO}_{x}}$ compared to without $F_{\mathrm{NO}_{x}}$.

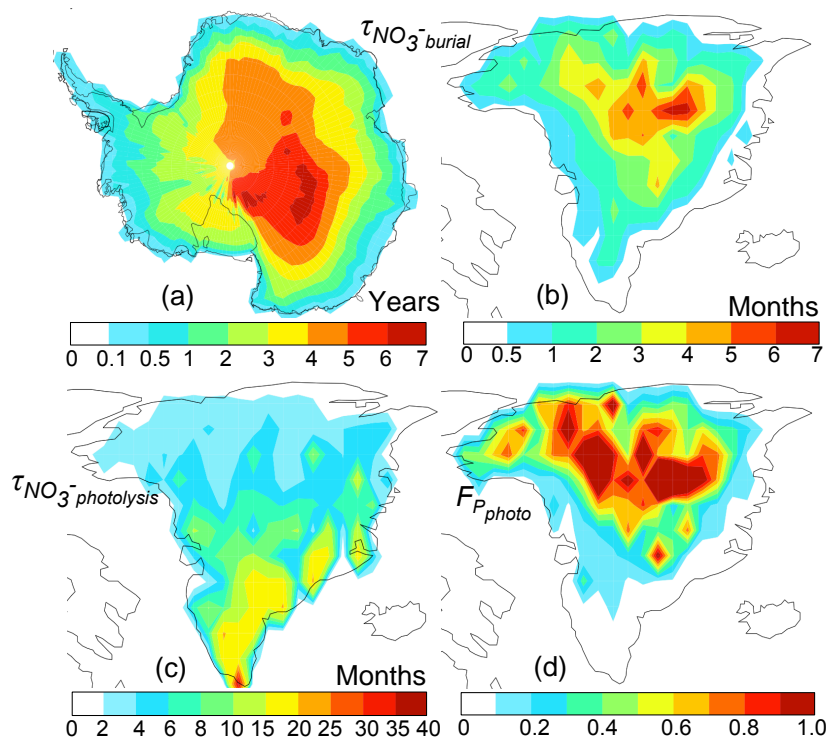

Figure 10. (a, b) Minimum lifetime of $\mathrm{NO}_{3}^{-}$against burial below snow photic zone $\left(\tau_{\mathrm{NO}_{3}^{-} \text {burial }}\right.$, Eq. 11). (c) Average lifetime of $\mathrm{NO}_{3}^{-}$ against photolysis in the photic zone in Greenland ( $\tau_{\mathrm{NO}_{3}^{-} \text {photolysis }}$, Eq. 13). (d) Ratio of $\tau_{\mathrm{NO}_{3}^{-} \text {burial }}$ to $\tau_{\mathrm{NO}_{3}^{-} \text {photolysis }}$ in Greenland $\left(F_{\mathrm{p}_{\text {photo }}}\right.$, Eq. 12$)$.

In Antarctica, the lifetime of $\mathrm{NO}_{3}^{-}$against burial is always longer than the lifetime of $\mathrm{NO}_{3}^{-}$against photolysis. However, in Greenland, the lifetime of $\mathrm{NO}_{3}^{-}$against burial may be shorter than the lifetime against photolysis due to the much shorter $\tau_{\mathrm{NO}_{3}^{-} \text {burial }}$ values. Figure $10 \mathrm{c}$ presents the lifetime of
$\mathrm{NO}_{3}^{-}$against photolysis in Greenland $\left(\tau_{\mathrm{NO}_{3}^{-} \text {photolysis }}\right.$, Eq. 13$)$, which ranges from less than a month in northern Greenland to 37 months in southern Greenland. The spatial pattern of $\tau_{\mathrm{NO}_{3}^{-} \text {photolysis }}$ is dependent on the mean summer (JJA) daily averaged downwelling surface irradiance values (not shown), which are highest in northern Greenland. Figure 10d shows $F_{\mathrm{p}_{\text {photo }}}$ (Eq. 12), which ranges from 0.003 to 1 across Greenland. Larger $F_{\mathrm{p}_{\text {photo }}}$ values in north-central Greenland suggest that the lifetime of photolabile $\mathrm{NO}_{3}^{-}$against photolysis is sufficiently short relative to its lifetime in the snow photic zone, allowing for a potentially large fraction of snow $\mathrm{NO}_{3}^{-}$to be photolyzed before burial beneath the photic zone. In southeastern Greenland, the lifetime of photolabile $\mathrm{NO}_{3}^{-}$against photolysis is longer than its lifetime in the snow photic zone, which will reduce post-depositional photolysis of snow $\mathrm{NO}_{3}^{-}$ in this region.

Figure 11a and $\mathrm{b}$ show the fraction of $\mathrm{NO}_{3}^{-}$gained or lost from the snow through photolysis $(f$, Eq. 10$)$, which ranges from -0.99 to 0.30 in Antarctica and -0.83 to 0.02 in Greenland. Throughout most of Antarctica and Greenland, values of $f$ are negative indicating that the photolysis of snow $\mathrm{NO}_{3}^{-}$ leads to net loss of $\mathrm{NO}_{3}^{-}$from the snowpack in most locations. Positive $f$ values indicate regions with net gain of $\mathrm{NO}_{3}^{-}$to the snow resulting from the spatial redistribution of $\mathrm{NO}_{3}^{-}$driven by snow photochemistry. In some regions of convergence, such as over the Ronne Ice Shelf in Antarctica, there is a net gain of snow-sourced $\mathrm{NO}_{3}^{-}$. There are sharp gradients in $f$ between the plateaus and the coasts. The largest loss of snow $\mathrm{NO}_{3}^{-}$occurs at the top of the plateaus, where most photolyzed $\mathrm{NO}_{3}^{-}$is transported away by katabatic winds. Along the coasts, the photolysis-driven loss of $\mathrm{NO}_{3}^{-}$from the snow is minimal due to high snow accumulation rates and transport of snow-sourced $\mathrm{NO}_{3}^{-}$from higher elevations. The spatial pattern of $f$ is influenced by the time that $\mathrm{NO}_{3}^{-}$remains in the photolytic zone $\left(\tau_{\mathrm{NO}_{3}^{-}}\right.$burial $)$, the concentration of photolabile $\mathrm{NO}_{3}^{-}\left(F_{\mathrm{p}}\right)$, and wind patterns across Antarctica and Greenland.

Figure $11 \mathrm{c}$ and $\mathrm{d}$ show modeled enrichments in ice-core $\delta^{15} \mathrm{~N}\left(\mathrm{NO}_{3}^{-}\right)$from photolysis-driven loss of $\mathrm{NO}_{3}^{-}$in snow. The $\delta^{15} \mathrm{~N}\left(\mathrm{NO}_{3}^{-}\right)$enrichments presented in Fig. $11 \mathrm{c}$ and $\mathrm{d}$ represent enrichments in $\delta^{15} \mathrm{~N}\left(\mathrm{NO}_{3}^{-}\right)$below the snow photic zone where $\mathrm{NO}_{3}^{-}$photolysis is not occurring, effectively integrating the total loss of $\mathrm{NO}_{3}^{-}$during its lifetime in the snow photic zone. Model-calculated ice-core $\delta^{15} \mathrm{~N}\left(\mathrm{NO}_{3}^{-}\right)$values range from 0 to $363 \%$ in Antarctica and 0 to $90 \%$ in Greenland and are highest at the tops of the plateaus. The modeled ice-core $\delta^{15} \mathrm{~N}\left(\mathrm{NO}_{3}^{-}\right)$enrichments resulting from the photolysis-driven loss of snow $\mathrm{NO}_{3}^{-}$are sensitive to the fractionation constant $(\varepsilon)$. In this study, the fractionation constant is varied over the full range of values reported in Erbland et al. (2013), Frey et al. (2009), and Shi et al. (2015); an $\varepsilon$ of $-90 \%$ increases modeled ice-core $\left.\delta^{15} \mathrm{~N}_{(} \mathrm{NO}_{3}^{-}\right)$by 


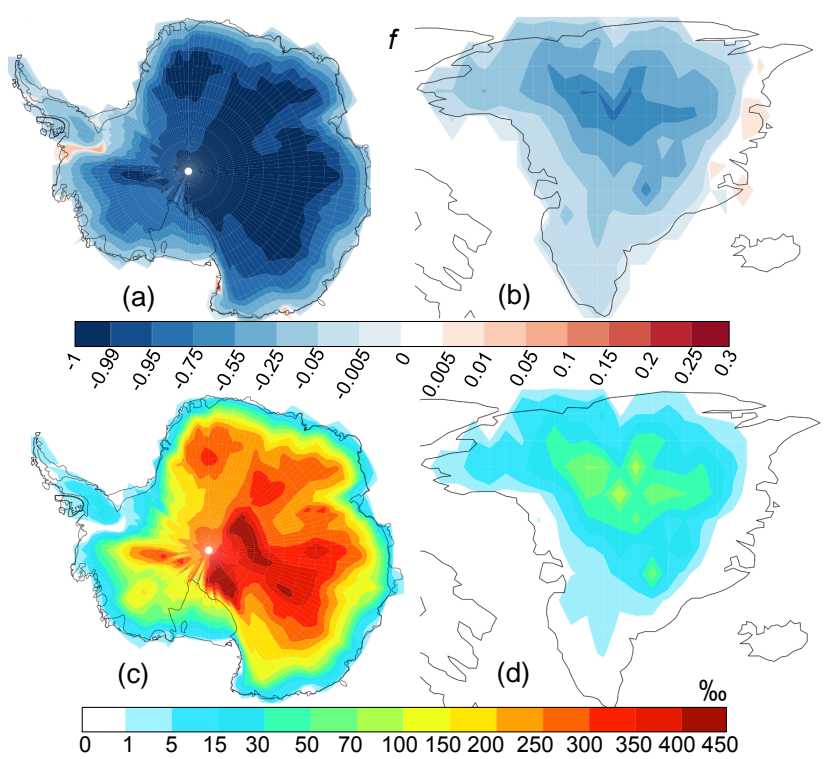

Figure 11. (a, b) Fraction of $\mathrm{NO}_{3}^{-}$gained (positive values) or lost (negative values) from the snow through photolysis ( $f$, Eq. 10). (c, d) Modeled enrichment in ice-core $\delta^{15} \mathrm{~N}_{\left(\mathrm{NO}_{3}^{-}\right.}$) (Eq. 14) due to photolysis-driven loss of $\mathrm{NO}_{3}^{-}$in snow. Note the varied color bar scale in (a) and (b).

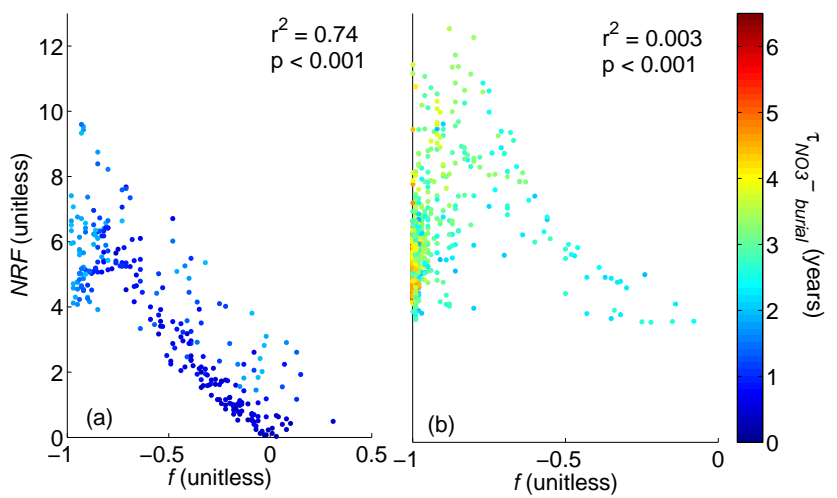

Figure 12. NRF versus $f$ values across Antarctica. (a) Regions where $\mathrm{NO}_{3}^{-}$remains in the photic zone for 2 years or less. (b) Regions where $\mathrm{NO}_{3}^{-}$remains in the photic zone for more than 2 years. The color scale represents the number of years $\mathrm{NO}_{3}^{-}$remains in the photic zone $\left(\tau_{\mathrm{NO}_{3}^{-} \text {burial }}\right)$.

a factor of 2 and an $\varepsilon$ of $-10 \%$ decreases modeled ice-core $\delta^{15} \mathrm{~N}\left(\mathrm{NO}_{3}^{-}\right)$by a factor of 5 across Antarctica and Greenland.

\subsection{Relationship between nitrogen recycling and photolytic loss of $\mathrm{NO}_{3}^{-}$in snow}

The degree of photolysis-driven loss of snow $\mathrm{NO}_{3}^{-}$is determined by both rates of photolysis and transport patterns across Antarctica and Greenland. The spatial patterns of recycling (NRF, Fig. 7) and loss ( $f$, Fig. 11a and b) differ

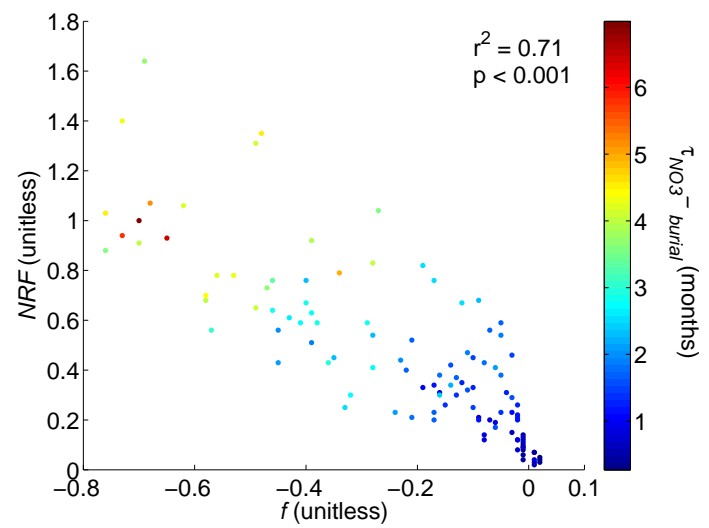

Figure 13. NRF versus $f$ values across Greenland. The color scale represents the minimum number of months that $\mathrm{NO}_{3}^{-}$remains in the photic zone $\left(\tau_{\mathrm{NO}_{3}^{-} \text {burial }}\right)$.

across Antarctica and Fig. 12 shows the relationship between $f$ and NRF across Antarctica. The magnitude of nitrogen recycling and degree of photolysis-driven loss of snow $\mathrm{NO}_{3}^{-}$ in Antarctica are well correlated $\left(r^{2}=0.74, p<0.001\right)$ in regions where $\mathrm{NO}_{3}^{-}$remains in the photic zone for less than 2 years $\left(\tau_{\mathrm{NO}_{3}^{-} \text {burial }}<2\right)$ (Fig. 12a). The relationship between recycling and loss breaks down $\left(r^{2}=0.03, p<0.001\right)$ in locations where $\mathrm{NO}_{3}^{-}$remains in the photic zone for more than 2 years (Fig. 12b). The relationship between recycling and loss weakens with increasing $\tau_{\mathrm{NO}_{3}^{-} \text {burial }}$ because recycling of reactive nitrogen occurs at or near the surface only, while loss of $\mathrm{NO}_{3}^{-}$occurs throughout the depth of snow photic zone. The time that $\mathrm{NO}_{3}^{-}$remains in the snow photic zone is dependent on snow accumulation rates and the concentrations of LAIs in snow, the latter of which is partially governed by snow accumulation rates. In the present climate, $\tau_{\mathrm{NO}_{3}^{-} \text {burial }}$ less than 2 years corresponds to snow accumulation rates higher than $130 \mathrm{~kg} \mathrm{~m}^{-2} \mathrm{a}^{-1}$ in Antarctica. Figure 13 shows the relationship between $f$ and NRF in Greenland. Nitrogen recycling and the degree of photolysis-driven loss of snow $\mathrm{NO}_{3}^{-}$are well correlated $\left(r^{2}=0.71, p<0.001\right)$ in Greenland, likely because $\mathrm{NO}_{3}^{-}$remains in the photic zone for less than 2 years across all of Greenland. Snow accumulation rates are higher than $130 \mathrm{~kg} \mathrm{~m}^{-2} \mathrm{a}^{-1}$ across much of Greenland, except in parts of central Greenland, where snow accumulation rates are between 60 and $100 \mathrm{~kg} \mathrm{~m}^{-2} \mathrm{a}^{-1}$. Differences in the relationship between snow accumulation rate and $\tau_{\mathrm{NO}_{3}^{-} \text {burial }}$ between Greenland and Antarctica are due to the higher concentrations of LAIs in Greenland snow.

\subsection{Comparison between Greenland and Antarctica}

Comparing model results in Greenland and Antarctica reveals information about how different parameters influence snow-sourced $\mathrm{NO}_{x}$ fluxes, nitrogen recycling, and 
photolysis-driven loss of snow $\mathrm{NO}_{3}^{-}$. Air temperatures (Fig. 2a, b) and annual snow accumulation rates (Fig. 2c, d) are generally higher in Greenland compared to Antarctica, and Greenland is also closer to pollution sources, which lead to differences in the magnitudes and spatial patterns of $F_{\mathrm{NO}_{x}}$, $\mathrm{NRF}$, and $f$ between these two regions.

The magnitude and spatial patterns of $F_{\mathrm{NO}_{x}}$ are influenced by snow photic zone depths (which are governed by snow LAI concentrations), snow $\mathrm{NO}_{3}^{-}$concentrations, and the quantum yield for $\mathrm{NO}_{3}^{-}$photolysis. The $e$-folding depths of UV actinic flux are shallower in Greenland (2$17 \mathrm{~cm})$ compared to Antarctica $(24-69 \mathrm{~cm})$ because concentrations of light-absorbing impurities in snow are higher in Greenland $\left(C_{\mathrm{BC}}=0.8-5.5 \mathrm{ng} \mathrm{g}^{-1}\right)$ compared to Antarctica $\left(C_{\mathrm{BC}}=0.08-0.6 \mathrm{ng} \mathrm{g}^{-1}\right)$. Similar to snow $C_{\mathrm{BC}}$, the proximity of Greenland to natural and anthropogenic $\mathrm{NO}_{x}$ sources leads to higher observed snow $\mathrm{NO}_{3}^{-}$values; the median of observed sub-surface snow $\mathrm{NO}_{3}^{-}$concentrations in Greenland (132 $\mathrm{ng} \mathrm{g}^{-1}$, Burkhart et al., 2009) is over 2 times higher than the median of observed sub-surface snow $\mathrm{NO}_{3}^{-}$concentrations in Antarctica (60 $\mathrm{ng} \mathrm{g}^{-1}$; Bertler et al., 2005). Similarly, modeled sub-surface snow $\mathrm{NO}_{3}^{-}$concentrations $\left(\left[\mathrm{NO}_{3}^{-}\right]_{\text {bot }} \times F_{\mathrm{p}}\right)$ are higher across much of Greenland compared to Antarctica. However, in coastal Antarctica and Greenland, modeled sub-surface snow $\mathrm{NO}_{3}^{-}$concentrations $\left(\left[\mathrm{NO}_{3}^{-}\right]_{\text {bot }} \times F_{\mathrm{p}}\right)$ are similar in magnitude because the fraction of dry-deposited $\mathrm{NO}_{3}^{-}$to total deposited $\mathrm{NO}_{3}^{-}\left(F_{\mathrm{p}}\right)$ is lower in Greenland, which lowers the concentration of photolabile $\mathrm{NO}_{3}^{-}$in the model. Additionally, modeled snow $\mathrm{NO}_{3}^{-}$ in the top $2 \mathrm{~cm}$ of snow ([ $\left.\mathrm{NO}_{3}^{-}\right]_{\text {top }}$ ) is generally higher across Antarctica ( $\left.\left[\mathrm{NO}_{3}^{-}\right]_{\text {top }}=78-360 \mathrm{ng} \mathrm{g}^{-1}\right)$ compared to Greenland $\left(\left[\mathrm{NO}_{3}^{-}\right]_{\text {top }}=8-121 \mathrm{ng} \mathrm{g}^{-1}\right)$ because $\mathrm{EF}=6$ in Antarctica and $\mathrm{EF}=1$ in Greenland. Lastly, summer temperatures are higher in Greenland (257-280 K) compared to Antarctica (237-271 K), which leads to higher quantum yields for $\mathrm{NO}_{3}^{-}$ photolysis in Greenland $(\phi=0.0032-0.0069)$ compared to Antarctica $(\phi=0.0015-0.0052)$.

Fluxes of snow-sourced $\mathrm{NO}_{x}\left(F_{\mathrm{NO}_{x}}\right)$ are somewhat higher in Greenland $\left(0.5-11 \times 10^{8}\right.$ molec cm $\left.\mathrm{cm}^{-2} \mathrm{~s}^{-1}\right)$ compared to Antarctica $\left(0.01-6.4 \times 10^{8}\right.$ molec $\left.\mathrm{cm}^{-2} \mathrm{~s}^{-1}\right)$ because $\phi$, and often sub-surface snow $\mathrm{NO}_{3}^{-}$concentrations $\left(\left[\mathrm{NO}_{3}^{-}\right]_{\text {bot }} \times F_{\mathrm{p}}\right)$, are higher in Greenland compared to Antarctica, even though snow photic zones are shallower across Greenland due to higher snow LAI concentrations. In Antarctica, the highest $F_{\mathrm{NO}_{x}}$ values occur midway up the plateau because photic zone depths and the quantum yields for $\mathrm{NO}_{3}^{-}$photolysis increase towards the coast while the concentrations of photolabile $\mathrm{NO}_{3}^{-}$decrease towards the coast. In Greenland, the highest $F_{\mathrm{NO}_{x}}$ values occur at the top of the plateau because both photic zone depths and concentrations of photolabile $\mathrm{NO}_{3}^{-}$ are at a maximum there. The quantum yield of $\mathrm{NO}_{3}^{-}$photolysis increases towards the coast, partially dampening the decreasing $F_{\mathrm{NO}_{x}}$ gradient towards the coast.
The NRF are much smaller in Greenland $(\mathrm{NRF}=0.01-$ 1.6) compared to Antarctica ( $\mathrm{NRF}=0.2-12$ ), suggesting that the degree of nitrogen recycling is much lower in Greenland. Although $F_{\mathrm{NO}_{x}}$ values are generally higher in Greenland compared to Antarctica, the degree of nitrogen recycling is lower in Greenland because of its proximity to pollution sources. Primary deposition of $\mathrm{NO}_{3}^{-}$is over an order of magnitude larger in Greenland compared to Antarctica. The total nitrate, $\mathrm{NO}_{x}, \mathrm{OH}$, and $\mathrm{O}_{3}$ boundary layer mixing ratio factor increases in Greenland are 16, 7, 3, and 2 times lower, respectively, compared to Antarctica due to its proximity to pollution sources.

$\mathrm{NO}_{3}^{-}$remains in the snow photic zone for a shorter period of time in Greenland (up to 7 months) compared to Antarctica (up to 6.5 years), because photic zones are shallower and snow accumulation rates are higher in Greenland. The assumed fraction of photolabile $\mathrm{NO}_{3}^{-}\left(F_{\mathrm{p}}\right)$ in the model is lower in Greenland compared to Antarctica because a higher fraction of $\mathrm{NO}_{3}^{-}$is wet deposited in Greenland. Additionally, the lifetime of photolabile $\mathrm{NO}_{3}^{-}$against burial beneath the snow photic zone $\left(\tau_{\mathrm{NO}_{3}^{-} \text {burial }}\right)$ is generally shorter than its lifetime against photolysis $\left(\tau_{\mathrm{NO}_{3}^{-} \text {photolysis }}\right)$ in Greenland, further limiting post-depositional loss and recycling of snow $\mathrm{NO}_{3}^{-}$.

In both Greenland and Antarctica, the highest fractions of photolysis-driven loss of snow $\mathrm{NO}_{3}^{-}(f)$ are located at the top of the plateaus and the lowest $f$ values are found at the coasts. Photolysis-driven loss of snow $\mathrm{NO}_{3}^{-}$is generally lower in Greenland compared to Antarctica because the fraction of photolabile $\mathrm{NO}_{3}^{-}\left(F_{\mathrm{p}}\right)$ and the time spent in the snow photic zone $\left(\tau_{\mathrm{NO}_{3}^{-} \text {burial }}\right)$ are lower in Greenland. Similar to the spatial patterns of $f$, modeled enrichments in icecore $\delta^{15} \mathrm{~N}\left(\mathrm{NO}_{3}^{-}\right)$are highest on the plateau and lowest at the coasts in both Antarctica and Greenland. $\delta^{15} \mathrm{~N}\left(\mathrm{NO}_{3}^{-}\right)$values in Antarctica are up to 4 times larger compared to Greenland because a higher fraction of $\mathrm{NO}_{3}^{-}$is lost from the snow via photolysis in Antarctica.

\subsection{Exploring the influence of chemical, optical, and physical parameters in snow on $\boldsymbol{F}_{\mathrm{NO}_{x}}$}

Snow accumulation rates have a major influence on snowsourced $\mathrm{NO}_{x}$ fluxes, nitrogen recycling and redistribution, and photolysis-driven loss of snow $\mathrm{NO}_{3}^{-}$via two mechanisms. By impacting burial rates, the snow accumulation rate impacts the time $\mathrm{NO}_{3}^{-}$spends in the snow photic zone. Snow accumulation rates influence light-absorbing impurity concentrations in snow, which impact the depth of the snow photic zone. Snow accumulation rates also influence concentrations of photolabile $\mathrm{NO}_{3}^{-}$in snow; both directly through dilution effects and indirectly by controlling the partitioning of wet and dry deposited $\mathrm{NO}_{3}^{-}$. Temperature also influences $F_{\mathrm{NO}_{x}}$ via the temperature-dependent quantum yield $(\phi)$, with higher temperatures leading to higher values of $\phi$. 
Table 3. Dependence of mean austral summer (DJF) flux of snow-sourced $\mathrm{NO}_{x}\left(\overline{F_{\mathrm{NO}_{x}}}\right)$ in Antarctica on quantum yield $(\phi)$, the fraction of photolabile $\mathrm{NO}_{3}^{-}\left(F_{\mathrm{p}}\right)$, snow $\mathrm{NO}_{3}^{-}$concentrations below $2 \mathrm{~cm}\left(\left[\mathrm{NO}_{3}^{-}\right]_{\text {bot }}\right)$, the radiation equivalent ice grain radius $\left(r_{\mathrm{e}}\right)$, the bulk snow extinction coefficient (Kext tot), the $\mathrm{NO}_{3}^{-}$concentration enhancement factor in the top $2 \mathrm{~cm}(\mathrm{EF})$, and snow black carbon concentration.

\begin{tabular}{|c|c|c|c|}
\hline Parameter & $\begin{array}{l}\text { Base-case values } \\
\left(\text { where } \overline{F_{\mathrm{NO}_{x}}}=0.5-7.8 \times 10^{8}\right. \\
\left.\text { molec cm }{ }^{-2} \mathrm{~s}^{-1}\right)\end{array}$ & $\begin{array}{l}\text { Values used in } \\
\text { sensitivity studies }\end{array}$ & $\begin{array}{l}\overline{F_{\mathrm{NO}_{x}}} \text { range in sensitivity studies } \\
\left.\left(\times 10^{8} \text { molec } \mathrm{cm}^{-2} \mathrm{~s}^{-1}\right)\right) \\
(\text { Factor changes compared to } \\
\overline{F_{\mathrm{NO}_{x}}} \text { in base case, unitless) }\end{array}$ \\
\hline Quantum yield $(\phi)$ & 0.02 molec photon $^{-1}$ a & 0.6 molec $_{\text {photon }}{ }^{-1}$ & $5-2600(10.0-333.0)$ \\
\hline Fraction of photolabile $\mathrm{NO}_{3}^{-}\left(F_{\mathrm{p}}\right)$ & $\begin{array}{l}0.01-0.99 \\
\text { (spatial variation, Fig. } 3 c \text { ) }\end{array}$ & Set to 1 everywhere & $3.7-9.6(1.2-7.4)$ \\
\hline Sub-surface snow $\mathrm{NO}_{3}^{-}\left(\left[\mathrm{NO}_{3}^{-}\right]_{\text {bot }}\right)$ & $60.0 \mathrm{ng} \mathrm{g}^{-1 \mathrm{~b}}$ & $30-120 \mathrm{ng} \mathrm{g}^{-1}$ & $0.3-15.8(0.6-2.0)$ \\
\hline $\begin{array}{l}\text { Radiation equivalent mean } \\
\text { ice grain radii }\left(r_{\mathrm{e}}\right)\end{array}$ & $\begin{array}{l}\text { Jan: } 332.0 \mu \mathrm{m}^{\mathrm{c}} \\
\text { Dec-Feb: } 198-332.0 \mu \mathrm{m}^{\mathrm{c}} \\
\text { Mar-Nov: } 86.0-332.0 \mu \mathrm{m}^{\mathrm{c}}\end{array}$ & $\begin{array}{l}\text { Study 1: } 332.0 \mu \mathrm{m}^{\mathrm{d}} \\
\text { Study 2: } 198-332.0 \mu \mathrm{m}^{\mathrm{d}} \\
\text { Study 3: } 86.0-332.0 \mu \mathrm{m}^{\mathrm{d}}\end{array}$ & $\begin{array}{l}0.5-10.2 \\
(1.0-1.3)\end{array}$ \\
\hline $\begin{array}{l}\text { Bulk snow extinction } \\
\text { coefficient (Kext tot) }\end{array}$ & $\begin{array}{l}1.7-6.9 \times 10^{3} \mathrm{~m}^{-1} \\
\text { (spatial variation) }\end{array}$ & $\begin{array}{l} \pm 20 \% \text { with respect to } \\
\text { base-case values }\end{array}$ & $\begin{array}{l}0.5-9.4 \\
(1.0-1.2)\end{array}$ \\
\hline $\begin{array}{l}\mathrm{NO}_{3}^{-} \text {enhancement } \\
\text { factor in top } 2 \mathrm{~cm}(\mathrm{EF})\end{array}$ & $6.0^{\mathrm{e}}$ & $1-10$ & $\begin{array}{l}0.5-9.3 \\
(1.0-1.2)\end{array}$ \\
\hline $\begin{array}{l}\text { Snow black carbon } \\
\left(C_{\mathrm{BC}}\right)\end{array}$ & $\begin{array}{l}0.08-0.6 \mathrm{ng} \mathrm{g}^{-1} \\
\text { (spatial variation, Fig. } 3 \mathrm{~b} \text { ) }\end{array}$ & $\begin{array}{l} \pm \text { factor of } 2 \text { with respect } \\
\text { to base-case values }\end{array}$ & $\begin{array}{l}0.5-8.6 \\
(1.0-1.1)\end{array}$ \\
\hline
\end{tabular}

${ }^{a}$ From Chu and Anastasio (2003) at $T=244 \mathrm{~K} .{ }^{\mathrm{b}}$ Median of ITASE campaign (Bertler et al., 2005). ${ }^{\mathrm{c}} r_{\mathrm{e}}$ is varied vertically and temporally, but uniformly across Antarctica based on Gallet et al. (2011) and Klein (2014). In January, $r_{\mathrm{e}}$ is constant with depth (332 $\left.\mu \mathrm{m}\right)$, in December and February, $r_{\mathrm{e}}$ ranges from $198 \mu \mathrm{m}$ at the snow surface to $332 \mu \mathrm{m}$ at $300 \mathrm{~cm}$ depth, and from March to November, $r_{\mathrm{e}}$ ranges from $86 \mu \mathrm{m}$ at the surface to $360 \mu \mathrm{m}$ at $300 \mathrm{~cm}$ depth. ${ }^{\mathrm{d}}$ In $r_{\mathrm{e}}$ sensitivity study 1 , the base-case "January" $r_{\mathrm{e}}$ profile is applied for every month. In $r_{\mathrm{e}}$ sensitivity study 2 , the base-case "December and February" $r_{\mathrm{e}}$ profile is applied for every month. In $r_{\mathrm{e}}$ sensitivity study 3 , the base-case

"March-November" $r_{\mathrm{e}}$ profile is applied for every month. ${ }^{\mathrm{e}}$ Median of observed EF (Dibb et al., 2004; Frey et al., 2009; Mayewski and Legrand, 1990; Rothlisberger et al., 2000).

In addition to exploring the sensitivity of snow $\mathrm{NO}_{3}^{-}$photolysis to meteorological parameters, the sensitivity of mean summer snow-sourced $\mathrm{NO}_{x}$ fluxes $\left(\overline{\mathrm{NO}_{x}}\right)$ to a variety of chemical, optical, and physical parameters in snow is explored in this section. Although the vast majority of these sensitivity studies focus on Antarctica because model computation time was limited, one sensitivity study was performed in Greenland and will be described below.

Table 3 shows the dependence of $\overline{F_{\mathrm{NO}_{x}}}$ on uncertainties in the quantum yield for $\mathrm{NO}_{3}^{-}$photolysis $(\phi)$, the fraction of photolabile $\mathrm{NO}_{3}^{-}\left(F_{\mathrm{p}}\right)$, sub-surface snow $\mathrm{NO}_{3}^{-}$concentrations $\left(\left[\mathrm{NO}_{3}^{-}\right]_{\text {bot }}\right.$ ), radiation equivalent mean ice grain radii $\left(r_{\mathrm{e}}\right)$, the bulk snow extinction coefficient $\left(\mathrm{Kext}_{\mathrm{tot}}\right)$, the $\mathrm{NO}_{3}^{-}$ concentration enhancement factor in the top $2 \mathrm{~cm}$ of snow (EF), and snow black carbon concentrations in Antarctica. The range of values for each of these parameters is determined by their estimated degree of uncertainty, in order to highlight the largest uncertainties in calculations of $\overline{F_{\mathrm{NO}_{x}}}$ The sensitivity study results are compared to $\overline{F_{\mathrm{NO}_{x}}}$ from the standard scenario, which is also described in Table 3. The $\overline{F_{\mathrm{NO}_{x}}}$ values from the standard scenario are slightly different than the $\overline{F_{\mathrm{NO}_{x}}}$ values presented in Fig. 5a because a spatially uniform $\phi$ is used in the standard scenario while a temperature-dependent $\phi$ is used in the rest of the manuscript (Figs. 5-13).

$\overline{F_{\mathrm{NO}_{x}}}$ is most sensitive to uncertainties in $\phi$, which increases $\overline{F_{\mathrm{NO}_{x}}}$ by up to a factor of 330 when $\phi$ from Zhu et al. (2010) $\left(0.6\right.$ molec photon $\left.^{-1}\right)$ is used compared to the $\phi$ in the standard scenario $\left(\phi=0.002\right.$ molec photon $^{-1}$ (Chu and Anastasio, 2003)). The second most influential parameter is the concentration of photolabile $\mathrm{NO}_{3}^{-}\left(\left[\mathrm{NO}_{3}^{-}\right]_{\text {bot }} \times F_{\mathrm{p}}\right)$. Assuming that all $\mathrm{NO}_{3}^{-}$is photolabile $\left(F_{\mathrm{p}}=1\right)$ increases $\overline{F_{\mathrm{NO}_{x}}}$ by up to a factor of 7.4 (at the coasts) with respect to the standard scenario. Use of the fraction of dry-deposited $\mathrm{NO}_{3}^{-}$ $\left(F_{\mathrm{p}}\right)$ to scale the concentration of photolabile $\mathrm{NO}_{3}^{-}$lowers $\overline{F_{\mathrm{NO}_{x}}}$ by up to $85 \%$ along the coast, but has little impact on the East Antarctic plateau due to the high fraction of dry deposited $\mathrm{NO}_{3}^{-}$. Uncertainties in $r_{\mathrm{e}}, \mathrm{Kext}_{\mathrm{tot}}, \mathrm{EF}$, and $C_{\mathrm{BC}}$ influence $\overline{F_{\mathrm{NO}_{x}}}$ by up to a factor of 1.3 compared to the standard scenario. In Greenland, EF is varied between 1 and 2, which is the range of observed EF presented in Dibb et al. (2007). Similar to Antarctica, varying EF from 1 to 2 increases $\overline{F_{\mathrm{NO}_{x}}}$ in Greenland by at most a factor of 1.2.

Calculated snow-sourced $\mathrm{NO}_{x}$ fluxes are by far most sensitive to uncertainties in the quantum yield for $\mathrm{NO}_{3}^{-}$photolysis and the concentration of photolabile $\mathrm{NO}_{3}^{-}$, which are likely related to one another. The results of Chu et al. (2003), 
Zhu et al. (2010), and Meusinger et al. (2014) suggest that the quantum yield is largely influenced by the location of $\mathrm{NO}_{3}^{-}$ in the ice grain; quantum yields tend to be lowest when $\mathrm{NO}_{3}^{-}$ is buried within the ice grain and highest when $\mathrm{NO}_{3}^{-}$is on the ice grain surface. Although we have not explicitly varied the quantum yield based upon $\mathrm{NO}_{3}^{-}$location in ice grains due to lack of information regarding the location, we alter the concentration of photolabile $\mathrm{NO}_{3}^{-}$based upon the ratio of dry to total deposited $\mathrm{NO}_{3}^{-}$This effectively assumes that only the dry-deposited fraction of $\mathrm{NO}_{3}^{-}$is on the surface of the snow grain and is photolabile, and that the wet-deposited $\mathrm{NO}_{3}^{-}$is trapped within an ice grain and thus is not photolabile. Using conservative $\phi$ values (Chu and Anastasio, 2003) and assuming that only dry-deposited $\mathrm{NO}_{3}^{-}$is photolabile may suggest that our calculated $F_{\mathrm{NO}_{x}}$ values represent a lower limit. However, no field-or laboratory-based information is available to assess our assumption that only dry-deposited $\mathrm{NO}_{3}^{-}$is photolabile; it is possible that the fraction of $\mathrm{NO}_{3}^{-}$that is photolabile is higher or lower than what we assume.

These sensitivity studies highlight the need for field, laboratory, and modeling studies to investigate factors influencing the quantum yield and concentration of photolabile $\mathrm{NO}_{3}^{-}$, such as the location of $\mathrm{NO}_{3}^{-}$within ice grains. We note that $F_{\mathrm{NO}_{x}}$ is also sensitive to the depth of the snow photic zone, which in turn is most sensitive to snow LAI concentrations and $r_{\mathrm{e}}$ (Zatko et al., 2013). By scaling the concentrations of total snow LAIs to $C_{\mathrm{BC}}$ in the model based on observations in Greenland and Antarctica (Zatko et al., 2013), we assume the same factor of 2 uncertainty in total LAI concentrations as we do for $C_{\mathrm{BC}}$. More measurements of snow LAIs other than black carbon are needed to confirm our assumptions about snow LAI concentrations and their associated uncertainty.

\section{Conclusions}

We have incorporated an idealized snowpack along with a snow radiative transfer model into a global chemical transport model (GEOS-Chem) and used this modeling framework to simulate the photolysis of snow $\mathrm{NO}_{3}^{-}$and calculate the associated snow-sourced flux and redistribution of nitrogen across Antarctica and Greenland. An important goal of this study is to explore the sensitivity of various chemical, optical, and physical properties of snow, as well as meteorology, on fluxes of snow-sourced $\mathrm{NO}_{x}$ and related nitrogen recycling, redistribution, and loss of $\mathrm{NO}_{3}^{-}$from the snow. This modeling framework is also used to examine the impact of snowpack $\mathrm{NO}_{3}^{-}$photolysis on boundary layer chemistry and the preservation of $\mathrm{NO}_{3}^{-}$concentration and nitrogen isotopes in ice cores across Antarctica and Greenland.

The calculated fluxes of snow-sourced $\mathrm{NO}_{x}$ in Antarctica and Greenland range from $0.01-6.4 \times 10^{8}$ molec $\mathrm{cm}^{2} \mathrm{~s}^{-1}$ and $0.5-11 \times 10^{8}$ molec $\mathrm{cm}^{2} \mathrm{~s}^{-1}$, respectively. The modeled spatial patterns of snow-sourced $\mathrm{NO}_{x}$ fluxes are determined by the spatial patterns of light-absorbing impurity (e.g., insoluble black carbon, dust, organics) concentrations in snow, photolabile $\mathrm{NO}_{3}^{-}$concentrations, and temperature-dependent quantum yields for $\mathrm{NO}_{3}^{-}$photolysis. In the model, the spatial patterns of light-absorbing impurities are influenced by snow accumulation rates and proximity to pollution sources, the spatial patterns of photolabile $\mathrm{NO}_{3}^{-}$in the model are influenced by the amount of wet-deposited $\mathrm{NO}_{3}^{-}$compared to total deposited $\mathrm{NO}_{3}^{-}$, and the spatial patterns of quantum yields of $\mathrm{NO}_{3}^{-}$photolysis are influenced by modeled surface air temperatures. Model sensitivity studies suggest that the magnitude of the snow-sourced $\mathrm{NO}_{x}$ flux is most sensitive to uncertainties in the quantum yield for $\mathrm{NO}_{3}^{-}$photolysis and the concentration of photolabile $\mathrm{NO}_{3}^{-}$, which are likely related to one another. The concentration of light-absorbing impurities in snow is also important for the flux of snow-sourced $\mathrm{NO}_{x}$, but we assume a much smaller degree of uncertainty in this parameter relative to uncertainties in the quantum yield and the concentrations of photolabile $\mathrm{NO}_{3}^{-}$. Fluxes of snowsourced $\mathrm{NO}_{x}$ are somewhat higher in Greenland compared to Antarctica because the quantum yields, and often photolabile $\mathrm{NO}_{3}^{-}$concentrations, are higher in Greenland because Greenland is warmer and closer to anthropogenic $\mathrm{NO}_{x}$ sources (e.g., northern hemisphere mid-latitudes). This is counteracted by the higher concentrations of snow light-absorbing impurities leading to shallower show photic zones in Greenland.

The nitrogen recycling factor (NRF) is dependent on the magnitude and spatial patterns of fluxes of primary $\mathrm{NO}_{3}^{-}$to the snow relative to fluxes of $\mathrm{NO}_{x}$ from the snow. NRF values greater than 1 suggest that nitrogen is recycled multiple times between the air and snow. NRF values range from 0.2 to 12 in Antarctica and are greater than 1 across most of Antarctica, with the exception of the coasts. NRF values range from 0.01 to 1.6 in Greenland and are only larger than 1 in central Greenland. The degree of nitrogen recycling is lower in Greenland because $\mathrm{NO}_{3}^{-}$deposition to snow is dominated by primary $\mathrm{NO}_{3}^{-}$deposition in Greenland, largely because Greenland is closer to pollution sources. Similarly, boundary layer mixing ratios of total nitrate, $\mathrm{NO}_{x}, \mathrm{OH}$, and $\mathrm{O}_{3}$ are less influenced by snow-sourced $\mathrm{NO}_{x}$ in Greenland because of its proximity to pollution sources.

This modeling framework can also be used to examine the impact of $\mathrm{NO}_{3}^{-}$photolysis on the preservation of $\mathrm{NO}_{3}^{-}$in ice cores. The time that $\mathrm{NO}_{3}^{-}$remains in the snow photic zone is dependent on snow accumulation rates both directly, and indirectly through their influence on light-absorbing impurity concentrations in snow. $\mathrm{NO}_{3}^{-}$remains in the snow photic zone for a much shorter period of time in Greenland (up to 7 months) compared to Antarctica (up to 6.5 years) because snow accumulation rates are higher in Greenland. The fraction of $\mathrm{NO}_{3}^{-}$lost from the snow through photolysis $(f)$ ranges from -0.99 to 0.30 in Antarctica and -0.83 to 0.02 in Greenland, where negative values indicate net loss of $\mathrm{NO}_{3}^{-}$ 
from the snow. The fraction of $\mathrm{NO}_{3}^{-}$lost from the snow is dependent on the time that $\mathrm{NO}_{3}^{-}$remains in the snow photic zone, the concentration of photolabile $\mathrm{NO}_{3}^{-}$, and wind patterns across Antarctica and Greenland. In both Antarctica and Greenland, net loss of snow $\mathrm{NO}_{3}^{-}$is highest on top of the plateaus and lowest at the coasts; some regions (e.g., Ronne and Ross Antarctic ice shelves) experience net gain of snow $\mathrm{NO}_{3}^{-}$due to the redistribution of snow-sourced nitrogen. The fraction of photolysis-driven loss of snow $\mathrm{NO}_{3}^{-}$ is lower in Greenland compared to Antarctica because the fraction of photolabile $\mathrm{NO}_{3}^{-}$and the time spent in the snow photic zone $\left(\tau_{\mathrm{NO}_{3}^{-} \text {burial }}\right)$ is lower in Greenland due to the higher snow accumulation rates and higher concentrations of snow light-absorbing impurities. The fraction of $\mathrm{NO}_{3}^{-}$lost from the snow through photolysis is used to calculate the enrichment in ice-core $\delta^{15} \mathrm{~N}_{\left(\mathrm{NO}_{3}^{-}\right)}$solely from photolysisdriven $\mathrm{NO}_{3}^{-}$loss in snow. The modeled enrichment in icecore $\delta^{15} \mathrm{~N}\left(\mathrm{NO}_{3}^{-}\right)$ranges from 0 to $363 \%$ in Antarctica and 0

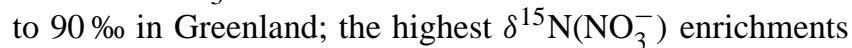
are calculated in central Antarctica and Greenland.

A significant relationship exists between nitrogen recycling and photolysis-driven loss of snow $\mathrm{NO}_{3}^{-}$in Antarctica when $\mathrm{NO}_{3}^{-}$remains in the photic zone for less than 2 years $\left(\tau_{\mathrm{NO}_{3}^{-} \text {burial }}<2\right)$, corresponding to a snow accumulation rate greater than $130 \mathrm{~kg} \mathrm{~m}^{-2} \mathrm{a}^{-1}$ in the present day. There is also a significant relationship between nitrogen recycling and photolysis-driven loss of snow $\mathrm{NO}_{3}^{-}$throughout all of Greenland, which is a region where snow accumulation rates are generally higher than $130 \mathrm{~kg} \mathrm{~m}^{-2} \mathrm{a}^{-1}$. Since the spatial variability of ice-core $\delta^{15} \mathrm{~N}\left(\mathrm{NO}_{3}^{-}\right)$is mainly determined by the fractional loss of snow $\mathrm{NO}_{3}^{-}$due to the large fractionation factor associated with its photolysis (Berhanu et al., 2014), observations of $\delta^{15} \mathrm{~N}\left(\mathrm{NO}_{3}^{-}\right)$in snow and ice can be used to estimate both the degree of recycling and loss of snow $\mathrm{NO}_{3}^{-}$ in Antarctica and Greenland as long as this condition is met. The relationship between recycling and loss can be useful for the interpretation of the oxygen isotopic composition of icecore $\mathrm{NO}_{3}^{-}$(e.g., Sofen et al., 2014), which is impacted by recycling of snow $\mathrm{NO}_{3}^{-}$. We note that the relationship between $\tau_{\mathrm{NO}_{3}^{-} \text {burial }}$ and snow accumulation rate may vary in different climates depending on the concentrations of light-absorbing impurities in snow (Geng et al., 2015).

This is the first modeling study to incorporate an idealized snowpack along with a snow radiative transfer model into a global chemical transport model. This modeling framework is used to investigate the impacts of snow-sourced $\mathrm{NO}_{x}$ on boundary layer chemistry and nitrogen recycling and redistribution, and its spatial variability, across Antarctica and Greenland. The modeled spatial patterns of nitrogen recycling, photolysis-driven loss of $\mathrm{NO}_{3}^{-}$from snow, and icecore $\delta^{15} \mathrm{~N}\left(\mathrm{NO}_{3}^{-}\right)$are each sensitive to multiple meteorological and chemical parameters, some of which are interdependent. Model sensitivity studies suggest that future field, lab- oratory, and modeling studies continue to focus on gaining a better understanding of the quantum yield for $\mathrm{NO}_{3}^{-}$photolysis and the concentration of photolabile $\mathrm{NO}_{3}^{-}$, which are likely related. More observations of the concentration of UV light-absorbing impurities in snow are also needed. Updated information about the quantum yield for $\mathrm{NO}_{3}^{-}$photolysis and the concentration of photolabile $\mathrm{NO}_{3}^{-}$in snow along with additional snow photochemical reactions can be incorporated into this modeling framework in the future, which will continue to improve our understanding of the impacts of snow photochemistry on boundary layer chemistry and the preservation of $\mathrm{NO}_{3}^{-}$and other photochemically active species in ice cores.

Acknowledgements. We acknowledge support from NSF PLR 1244817, NSF PLR 0944537, NSF PLR 1446904, and an EPA STAR graduate fellowship to M. C. Zatko. The authors thank Steve Warren, Sarah Doherty, Thomas Grenfell, and Quentin Libois for helpful discussions about light-absorbing impurities in snow and their influence on snow photochemistry. We thank Joseph Erbland for many helpful comments and discussions about nitrogen recycling. Joel Thornton and Lyatt Jaeglé also provided many helpful comments about this work. We also thank Paul Hezel and Yanxu Zhang for helping M. C. Zatko learn GEOS-Chem. We thank Qianjie Chen for helpful feedback on paper drafts and Martin Schneebeli for providing useful advice about snow grain profiles in Antarctic snow. The authors thank the editor and two anonymous reviewers for helpful comments.

Edited by: E. Browne

\section{References}

Allen, D., Pickering, K., Duncan, B., and Damon, M.: Impact of lightning NO emissions on North American photochemistry as determined using the Global Modeling Initiative (GMI) model, J. Geophys. Res., 115, D22301, doi:10.1029/2010JD014062, 2010.

Alexander, B., Savarino, J., Kreutz, K. J., and Thiemens, M. H.: Impact of preindustrial biomass burning emissions on the oxidation pathways of tropospheric sulphur and nitrogen, J. Geophys. Res., 109, D08303, doi:10.1029/2003JD004218, 2004.

Amos, H. M., Jacob, D. J., Holmes, C. D., Fisher, J. A., Wang, Q., Yantosca, R. M., Corbitt, E. S., Galarneau, E., Rutter, A. P., Gustin, M. S., Steffen, A., Schauer, J. J., Graydon, J. A., Louis, V. L. St., Talbot, R. W., Edgerton, E. S., Zhang, Y., and Sunderland, E. M.: Gas-particle partitioning of atmospheric $\mathrm{Hg}$ (II) and its effect on global mercury deposition, Atmos. Chem. Phys., 12, 591-603, doi:10.5194/acp-12-591-2012, 2012.

Anastasio, C. and Chu, L.: Photochemistry of nitrous acid (HONO) and nitrous acidium ion $\left(\mathrm{H}_{2} \mathrm{ONO}^{+}\right)$in aqueous solution and ice, Environ. Sci. Technol., 43, 1108-1114, 2009.

Beine, H., Anastastio, C., Esposito, G., Patten, K., Wilkening, E., Domine, F., Voisin, D., Barret, M., Houdier, S., and Hall, S.: Soluble, light-absorbing species in snow at Barrow, Alaska, J. Geophys. Res., 116, D00R05, doi:10.1029/2011JD016181, 2011. 
Bergin, M. H., Jaffrezo, J.-L., Davidson, C. I., Dibb, J. E., Pandis, S. N., Hillamo, R., Maenhaut, M., Kuhns, H. D., and Makela, T.: The contributions of snow, fog, and dry deposition to the summer flux of anions and cations at Summit, Greenland, J. Geophys. Res., 100, 16275-16288, 1995.

Berhanu, T. A., Meusinger, C., Erbland, J., Jost, R., Bhattcharya, S. K., Johnson, M. S., and Savarino, J.: Laboratory study of nitrate photolysis in Antarctic snow. I I. Isotopic effects and wavelength dependence, J. Chem. Phys., 140, 244306, doi:10.1063/1.4882899, 2014.

Bertler, N., Mayewski, P. A., Aristarain, A., Barrett, P., Becagli, S., Bernardo, R., Bo, S., Xiao, C., Curran, M., Qin, D., Dixon, D., Ferron, F., Fischer, H., Frey, M., Frezzotti, M., Fundel, F., Genthon, C., Gragnani, R., Hamilton, G., Handley, M., Hong, S., Isaksson, E., Kang, J., Ren, J., Kamiyama, K., Kanamori, S., Karkas, E., Karlof, L., Kaspari, S., Kreutz, K., Kurbatov, A., Meyerson, E., Ming, Y., Zhang, M., Motoyama, H., Mulvaney, R., Oerter, H., Osterberg, E., Proposito, M., Pyne, A., Ruth, U., Simoes, J., Smith, B., Sneed, S., Teinila, K., Traufetter, F., Udisti, R., Virkkula, A., Watanabe, O., Williamson, R., Winther, J- G., Li, Y., Wolff, E., Li, Z., and Zielinski, A.: Snow chemistry across Antarctica, Ann. Glaciol., 41, 167-179, 2005.

Bey, I., Jacob, D. J., Yantosca, R. M., Logan, J. A., Field, B. D., Fiore, A. M., Li, Q., Liu, H. Y., Mickley, L. J., and Schultz, M. G.: Global modeling of tropospheric chemistry with assimilated meteorology: model description and evaluation, J. Geophys. Res., 106, 23073-23095, 2001.

Bian, H. S. and Prather, M. J.: Fast-J2: Accurate simulation of stratospheric photolysis in global chemical models, J. Atmos. Chem., 41, 281-296, 2002.

Bloss, W. J., Lee, J. D., Heard, D. E., Salmon, R. A., Bauguitte, S. J.-B., Roscoe, H. K., and Jones, A. E.: Observations of $\mathrm{OH}$ and $\mathrm{HO}_{2}$ radicals in coastal Antarctica, Atmos. Chem. Phys., 7, 4171-4185, doi:10.5194/acp-7-4171-2007, 2007.

Blunier, T., Gregoire, F. L., Jacobi, H.-W., and Quansah, E.: Isotopic view on nitrate loss in Antarctic surface snow, Geophys. Res. Lett., 32, L13501, doi:10.1029/2005GL023011, 2005.

Boxe, C. S., Colussi, A. J., Hoffmann, M. R., Murphy, J. G., Wolldridge, P. J., Bertram, T. H., and Cohen, R. C.: Photochemical production and release of gaseous $\mathrm{NO}_{2}$ from nitrate-doped water ice, J. Phys. Chem. A, 109, 8520-8525, 2005.

Burkhart, J. F., Bales, R. C., McConnell, J. R., Hutterli, M. A., and Frey, M. M.: Geographic variability of nitrate deposition and preservation over the Greenland ice sheet, J. Geophys. Res., 114, D06301, doi:10.1029/2008JD010600, 2009.

Casasanta, G., Pietroni, I., Petenko, I., and Argentini, S.: Observed and modelled convective mixing-layer height and Dome C, Antarctica, Bound.-Lay. Meteorol., 151, 597-608, doi:10.1007/s10546-014-9907-5, 2014.

Chen, G., Davis, D., Crawford, J., Hutterli, L. M., Huey, L. G., Slusher, D., Mauldin, L., Eisele, F., Tanner, D., Dibb, J., Buhr, M., McConnell, J., Lefer, B., Shetter, R., Blake, D., Song, C. H., Lombardi, K., and Arnoldy, J.: A reassessment of $\mathrm{HO}_{x}$ South Pole chemistry based on observations recorded during ISCAT 2000, Atmos. Environ., 38, 5451-5461, 2004.

Chen, G., Huey, L. G., Crawford, J. H., Olson, J. R., Hutterli, M. A., Sjostedt, S., Tanner, D., Dibb, J., Lefer, B., Blake, N., Davis, D., and Stohl, A.: An assessment of the polar $\mathrm{HO}_{x}$ photochemical budget based on 2003 Summit Greenland Field Observations, Atmos. Environ., 41, 7806-7820, 2007.

Cho, H., Shepson, P. B., Barrie, L. A., Cowin, J. P., and Zaveri, R.: NMR investigation of the quasi-brine layer in ice/brine mixtures, J. Phys. Chem. B., 106, 11226-11232, 2002.

Chu, L. and Anastasio. C.: Quantum yields of hydroxyl radicals and nitrogen dioxide from the photolysis of nitrate on ice, J. Phys. Chem. A, 107, 9594-9602, 2003.

Cohen, L., Helmig, D., Neff, W. D., Grachev, A. A., and Fairall, C. W.: Boundary-layer dynamics and its influence on atmospheric chemistry at Summit, Greenland, Atmos. Environ., 41, 5044-5060, 2007.

Davidson, C. I., Harrington, J. R., Stephenson, M. J., Small, M. J., Boscoe, F. P., and Gandley, R. E.: Seasonal variations in sulfate, nitrate, and chloride in the Greenland ice sheet: relation to atmospheric concentrations, Atmos. Environ., 23, 2483-2493, 1989.

Davis, D., Chen, G., Buhr, M., Crawford, J., Lenschow, D., Lefer, B., Shetter, R., Eisele, F., Mauldin, L., and Hogan, A.: South Pole $\mathrm{NO}_{x}$ chemistry: an assessment of factors controlling variability and absolute levels, Atmos. Environ., 38, 5375-5388, 2004.

Davis, D. D., Seelig, J., Huey, G., Crawford, J., Chen, G., Wang, Y., Buhr, M., Helmig, D., Neff, W., Blake, D., Arimoto, R., and Eisele, F.: A reassessment of Antarctic plateau reactive nitrogen based on ANTCI 2003 airborne and ground based measurements, Atmos. Environ., 42, 2831-2848, doi:10.1016/j.atmosenv.2007.07.039, 2008.

Dibb, J. E., Talbot, R. W., and Bergin, M. H.: Soluble acidic species in air and snow at Summit, Greenland, Geophys. Res. Lett., 21, 1627-1630, 1994.

Dibb, J. E., Huey, G. L., Slusher, D. L., and Tanner, D. J.: Soluble reactive nitrogen oxides at South Pole during ISCAT 2000, Atmos. Environ., 38, 5399-5409, 2004.

Dibb, J. E., Whitlow, S. I., and Arsenault, M.: Seasonal variations in the soluble ion content of snow at Summit, Greenland: constraints from three years of daily surface snow samples, Atmos. Environ., 41, 5007-5019, doi:10.1016/j.atmosenv.2006.12.010, 2007.

Doherty, S. J., Warren, S. G., Grenfell, T. C., Clarke, A. D., and Brandt, R. E.: Light-absorbing impurities in Arctic snow, Atmos. Chem. Phys., 10, 11647-11680, doi:10.5194/acp-1011647-2010, 2010.

Doherty, S. J., Grenfell, T. C., Forsstrom, S., Hegg, D. L., Brandt, R. E., and Warren, S. G.: Observed vertical redistribution of black carbon and other insoluble light-absorbing particles in melting snow, J. Geophys. Res.-Atmos., 118, 5553-5569, doi:10.1002/jgrd.50235, 2013.

Domine, F. and Shepson, P. B.: Air-snow interactions and atmospheric chemistry, Science, 297, 1506-1510, 2002.

Domine, F., Bock, J., Voisin, D., and Donaldson, D. J.: Can we model snow photochemistry? Problems with the current approaches, J. Phys. Chem. A, 117, 4733-4749, doi:10.1021/jp3123314, 2013.

Drue, C. and Heinemann, G.: Characteristics of intermittent turbulence in the upper stable boundary layer over Greenland, Boundary-Layer Meteorol., 124, 361-381, doi:10.1007/s10546007-9175-8, 2007.

Erbland, J., Vicars, W. C., Savarino, J., Morin, S., Frey, M. M., Frosini, D., Vince, E., and Martins, J. M. F.: Air-snow transfer 
of nitrate on the East Antarctic Plateau - Part 1: Isotopic evidence for a photolytically driven dynamic equilibrium in summer, Atmos. Chem. Phys., 13, 6403-6419, doi:10.5194/acp-136403-2013, 2013.

Erbland, J., Savarino, J., Morin, S., France, J. L., Frey, M. M., and King, M. D.: Air-snow transfer of nitrate on the East Antarctic Plateau - Part 2: An isotopic model for the interpretation of deep ice-core records, Atmos. Chem. Phys., 15, 12079-12113, doi:10.5194/acp-15-12079-2015, 2015.

Fisher, J. A., Jacob, D. J., Wang, Q., Bahreini, R., Carouge, C. C., Cubison, M. J., Dibb, J. E., Diehl, T., Jimenez, J. L., Leibensperger, E. M., Meinders, M. B. T., Pye, H. O. T., Quinn, P. K., Sharma, S., van Donkelaar, A., and Yantosca, R. M.: Sources, distribution, and acidity of sulfateammonium aerosol in the Arctic in winter-spring, Atmos. Environ., 45, 7301-7318, 2011.

Frey, M. M., Savarino, J., Morin, S., Erbland, J., and Martins, J. M. F.: Photolysis imprint in the nitrate stable isotope signal in snow and atmosphere of East Antarctica and implications for reactive nitrogen cycling, Atmos. Chem. Phys., 9, 86818696, doi:10.5194/acp-9-8681-2009, 2009.

Frey, M. M., Brough, N., France, J. L., Anderson, P. S., Traulle, O., King, M. D., Jones, A. E., Wolff, E. W., and Savarino, J.: The diurnal variability of atmospheric nitrogen oxides (NO and $\mathrm{NO}_{2}$ ) above the Antarctic Plateau driven by atmospheric stability and snow emissions, Atmos. Chem. Phys., 13, 3045-3062, doi:10.5194/acp-13-3045-2013, 2013.

Freyer, H. D., Kley, D., Voiz-Thomas, A., and Kobel, K.: On the interaction of isotopic exchange processes with photochemical reactions in atmospheric oxides of nitrogen, J. Geophys. Res.Atmos., 98, 14791-14796, 1993.

Gallet, J.-C., Domine, F., Arnaud, L., Picard, G., and Savarino, J.: Vertical profile of the specific surface area and density of the snow at Dome C and on a transect to Dumont D'Urville, Antarctica -albedo calculations and comparison to remote sensing products, The Cryosphere, 5, 631-649, doi:10.5194/tc-5-631-2011, 2011.

Geng, L., Alexander, B., Cole-Dai, J., Steig, E. J., Savarino, J., Sofen, E. D., and Schauer, A. J.: Nitrogen isotopes in ice core nitrate linked to anthropogenic atmospheric acidity change, P. Natl. Acad. Sci., 111, 5808-5812, doi:10.1073/pnas.1319441111, 2014a.

Geng, L., Cole-Dai, J., Alexander, B., Erbland, J., Savarino, J., Schauer, A. J., Steig, E. J., Lin, P., Fu, Q., and Zatko, M. C.: On the origin of the occasional spring nitrate peak in Greenland snow, Atmos. Chem. Phys., 14, 13361-13376, doi:10.5194/acp14-13361-2014, 2014b.

Geng, L., Zatko, M. C., Alexander, B., Fudge, T. J., Schauer, A. J., Murray, L. T., and Mickley, L. J.: Effects of post-depositional processing on nitrogen isotopes of nitrate in the Greenland Ice Sheet Project 2 (GISP2) ice core, Geophys. Res. Lett., 42, 53465354, doi:10.1002/2015GL064218, 2015.

Grannas, A. M., Jones, A. E., Dibb, J., Ammann, M., Anastasio, C., Beine, H. J., Bergin, M., Bottenheim, J., Boxe, C. S., Carver, G., Chen, G., Crawford, J. H., Dominé, F., Frey, M. M., Guzmán, M. I., Heard, D. E., Helmig, D., Hoffmann, M. R., Honrath, R. E., Huey, L. G., Hutterli, M., Jacobi, H. W., Klán, P., Lefer, B., McConnell, J., Plane, J., Sander, R., Savarino, J., Shepson, P. B., Simpson, W. R., Sodeau, J. R., von Glasow, R.,
Weller, R., Wolff, E. W., and Zhu, T.: An overview of snow photochemistry: evidence, mechanisms and impacts, Atmos. Chem. Phys., 7, 4329-4373, doi:10.5194/acp-7-4329-2007, 2007.

Grenfell, T. C.: A radiative transfer model for sea ice with vertical structure variations, J. Geophys. Res., 96, 16991-17001, 1991.

Grenfell, T. C., Warren, S. G., and Mullen, P. C.: Reflection of solar radiation by the Antarctic snow surface at ultraviolet, visible, and near-infrared wavelengths, J. Geophys. Res., 99, 18669-18684, 1994.

Handorf, D., Foken, T., and Kottmeier, C.: The stable atmospheric boundary layer over an Antarctic ice sheet, Bound.-Lay. Meteorol., 91, 165-189, 1999.

Hastings, M. G., Steig, E. J., and Sigman, D. M.: Seasonal variations in $\mathrm{N}$ and $\mathrm{O}$ isotopes of nitrate in snow at Summit, Greenland: Implications for the study of nitrate in snow and ice cores, J. Geophys. Res., 109, D20306, doi:10.1029/2004JD004991, 2004.

Hastings, M. G., Sigman, D. M., and Steig, E. J.: Glacial/interglacial changes in the isotopes of nitrate from the Greenland Ice Sheet Project (GISP2) ice core, Global Biogeochem. Cy., 19, GB4024, doi:10.1029/2005GB002502, 2005.

Heaton, T. H. E., Spiro, B., and Robertson, M. C. S.: Potential canopy influences on the isotopic composition of nitrogen and sulphur in atmospheric deposition, Oecologia, 109, 600-607, 1997.

Helmig, D., Boulter, J., David, D., Birks, J. W., Cullen, N. J., Steffen, K., Johnson, B. J., and Oltmans, S. J.: Ozone and meteorological boundary-layer conditions at Summit, Greenland, during 3-21 2000, Atmos. Environ., 36, 2595-2608, 2002.

Helmig, D., Johnson, B., Oltmans, S. J., Neff, W., Eisele, F., and Davis, D.: Elevated ozone in the boundary layer at South Pole, Atmos. Environ., 42, 2788-2803, 2008.

Holtslag, A. A. M. and Boville, B.: Local versus nonlocal boundary layer diffusion in a global climate model, J. Climate, 6, 18251842, 1993.

Honrath, R. E., Lu, Y., Peterson, M. C., Dibb, J. E., Arsenault, M. A., Cullen, N. J., and Steffen, K.: Vertical fluxes of $\mathrm{NO}_{x}$, $\mathrm{HONO}$, and $\mathrm{HNO}_{3}$ above the snowpack at Summit, Greenland, Atmos. Environ., 36, 2629-2640, 2002.

Hudman, R. C., Moore, N. E., Mebust, A. K., Martin, R. V., Russell, A. R., Valin, L. C., and Cohen, R. C.: Steps towards a mechanistic model of global soil nitric oxide emissions: implementation and space based-constraints, Atmos. Chem. Phys., 12, 7779-7795, doi:10.5194/acp-12-7779-2012, 2012.

Jarvis, J. C., Hastings, M. G., Steig, E. J., and Kunasek, S. A.: Isotopic ratios in gas-phase $\mathrm{HNO}_{3}$ and snow nitrate at Summit, Greenland, J. Geophys. Res., 114, D17301, doi:10.1029/2009JD012134, 2009.

Jin, Z., Charlock, T. P., Yang, P., Xie, Y., and Miller, W.: Snow optical properties for different particle shapes with application to snow grain size retrieval and MODIS/CERES radiance comparison over Antarctica, Remote. Sens. Environ., 112, 3563-3581, 2008.

Jones, A. E., Anderson, P. S., Wolff, E. W., Turner, J., Rankin, A. M., and Colwell, S. R.: A role for newly forming sea ice in springtime polar tropospheric ozone loss? Observational evidence from Halley station, Antarctica, J. Geophys. Res., 111, D08306, doi:10.1029/2005JD006566, 2006.

Jones, A. E., Wolff, E. W., Salmon, R. A., Bauguitte, S. J.-B., Roscoe, H. K., Anderson, P. S., Ames, D., Clemitshaw, K. C., 
Fleming, Z. L., Bloss, W. J., Heard, D. E., Lee, J. D., Read, K. A., Hamer, P., Shallcross, D. E., Jackson, A. V., Walker, S. L., Lewis, A. C., Mills, G. P., Plane, J. M. C., Saiz-Lopez, A., Sturges, W. T., and Worton, D. R.: Chemistry of the Antarctic Boundary Layer and the Interface with Snow: an overview of the CHABLIS campaign, Atmos. Chem. Phys., 8, 3789-3803, doi:10.5194/acp-8-3789-2008, 2008.

King, J. C., Argentini, S. A., and Anderson, P. S.: Contrasts between the summertime surface energy balance and boundary layer structure at Dome C and Halley stations, Antarctica, J. Geophys. Res., 111, D02105, doi:10.1029/2005JD006130, 2006.

Klein, K.: Variability in Dry Antarctic Firn; Investigations on Spatially Distributed Snow and Firn Samples from Dronning Maud Land, Antarctica, PhD thesis, Universität Bremen, Germany, available at: http://nbn-resolving.de/urn:nbn:de:gbv: 46-00104117-15, last access: 15 April 2014.

Kodama, Y., Wendler, G., and Ishikawa, N.: The diurnal variation of the boundary layer in summer in Adelie Land, Eastern Antarctica, J. Appl. Meteorol., 28, 16-24, 1989.

Konig-Langlo, G., King, J., and Pettre, P.: Climatology of the three coastal Antarctic stations Durmont D'urville, Neumayer, and Halley, J. Geophys. Res., 103, 10935-10946, 1998.

Lee, H., Henze, D. K., Alexander, B., and Murray, L. T.: Investigating the sensitivity of surface-level nitrate seasonality in Antarctica to primary sources using a global model, Atmos. Environ., 89, 757-767, doi:10.1016/j.atmosenv.2014.03.003, 2014.

Legrand, M. R. and Kirchner, S.: Origins and variations of nitrate in South Polar precipitation, J. Geophys. Res., 95, 3493-3507, 1990.

Levy, H., Moxim, W. J., Klonecki, A. A., and Kasibhatla, P. S.: Simulated tropospheric $\mathrm{NO}_{x}$ : its evaluation, global distribution and individual source contributions, J. Geophys. Res., 104, 26279 26306, 1999.

Libois, Q., Picard, G., France, J. L., Arnaud, L., Dumont, M., Carmagnola, C. M., and King, M. D.: Influence of grain shape on light penetration in snow, The Cryosphere, 7, 1803-1818, doi:10.5194/tc-7-1803-2013, 2013.

Lin, J. T. and McElroy, M. B.: Impacts of boundary layer mixing on pollutant vertical profiles in the lower troposphere: Implications to satellite remote sensing, Atmos. Environ., 44, 17261749, doi:10.1016/j.atmosenv.2010.02.009, 2010.

Liu, H., Jacob, D. J., Bey, I., and Yantosca, R. M.: Constraints from ${ }^{210} \mathrm{~Pb}$ and ${ }^{7} \mathrm{Be}$ on wet deposition and transport in a global threedimensional chemical tracer model driven by assimilated meteorological fields, J. Geophys. Res., 106, 12109-12128, 2001.

Logan, J. A.: Nitrogen oxides in the troposphere: global and regional budgets, J. Geophys. Res., 88, 10785-10807, doi:10.1029/JC088iC15p10785, 1983.

Mack, J. and Bolton, J. R.: Photochemistry of nitrite and nitrate in aqueous solution: a review, J. Photoch. Photobio. A, 128, 1-13, 1999.

Mao, J., Jacob, D. J., Evans, M. J., Olson, J. R., Ren, X., Brune, W. H., Clair, J. M. St., Crounse, J. D., Spencer, K. M., Beaver, M. R., Wennberg, P. O., Cubison, M. J., Jimenez, J. L., Fried, A., Weibring, P., Walega, J. G., Hall, S. R., Weinheimer, A. J., Cohen, R. C., Chen, G., Crawford, J. H., McNaughton, C., Clarke, A. D., Jaeglé, L., Fisher, J. A., Yantosca, R. M., Le Sager, P., and Carouge, C.: Chemistry of hydrogen oxide radicals $\left(\mathrm{HO}_{x}\right)$ in the Arctic troposphere in spring, Atmos. Chem. Phys., 10, 5823 5838, doi:10.5194/acp-10-5823-2010, 2010.

Mayewski, P. A. and Legrand, M. R.: Recent increase in nitrate concentration of Antarctic snow, Nature, 346, 258-260, 1990.

Meusinger, C., Berhanu, T. A., Erbland, J., Savarino, J., and Johnson, M. S.: Laboratory study of nitrate photolysis in Antarctic snow. I. Observed quantum yield, domain of photolysis, and secondary chemistry, J. Chem. Phys., 140, 244305, doi:10.1063/1.4882898, 2014.

Morin, S., Savarino, J., Frey, M. M., Domine, F., Jacobi, H.-W., Kaleschke, L., and Martins, J. M. F.: Comprehensive isotopic composition of atmospheric nitrate in the Atlantic Ocean boundary layer from $65^{\circ} \mathrm{S}$ to $79^{\circ} \mathrm{N}$, J. Geophys. Res., 114, D05303, doi:10.1029/2008JD010696, 2009.

Mulvaney, R., Wagenbach, D., and Wolff, E. W.: Postdepositional change in snowpack nitrate from observation of year-round near-surface snow in coastal Antarctica, J. Geophys. Res., 103, 11021-11031, 1998.

Murray, L. T., Jacob, D. J., Logan, J. A., Hudman, R. C., and Koshak, W. J.: Optimized regional and interannual variability of lightning in a global chemical transport model constrained by LIS/OTD satellite data, J. Geophys. Res., 117, D20307, doi:10.1029/2012JD017934, 2012.

Neff, W., Helmig, D., Grachev, A., and Davis, D.: A study of boundary layer behaviour associated with high concentrations at the South Pole using a minisoder, tethered balloon, and a sonic anemometer, Atmos. Environ., 42, 2762-2779, 2008.

Oliver, J. G. J., Van Aardenne, J. A., Dentener, F. J., Pagliari, V., Ganzeveld, L. N., and Peters, J. A. H. W.: Recent trends in global greenhouse gas emissions: regional trends 1970-2000 and spatial distribution of key sources in 2000, Environm. Sci., 2, 81-99, doi:10.1080/15693430500400345, 2005.

Oncley, S., Buhr, M., Lenschow, D., Davis, D., and Semmer, S.: Observations of summertime NO fluxes and boundary-layer height at the South Pole during ISCAT 2000 using scalar similarity, Atmos. Environ., 38, 5389-5398, doi:10.1016/j.atmosenv.2004.05.053, 2004.

Parish, T. R. and Bromwich, D. H.: Reexamination of the nearsurface airflow over the Antarctic continent and implications on atmospheric circulations at high southern latitudes, Mon. Weather Rev., 135, 1961-1973, 2007.

Pratt, K. A., Custard, K. D., Shepson, P. B., Douglas, T. A., Pohler, D., General, S., Zielcke, J., Simpson, W. R., Platt, U., Tanner, D. J., Huey, L. G., Carlsen, M., and Stirm, B. H.: Photochemical production of molecular bromine in Arctic surface snowpacks, Nature, 6, 351-356, doi:10.1038/NGEO1779, 2013.

Price, C. and Rind, D.: A simple lightning parameterization for calculating global lightning distributions, J. Geophys. Res., 97, 9919-9933, 1992.

Rothlisberger, R., Hutterli, M. A., Sommer, S., Wolff, E. W., and Mulvaney, R.: Factors controlling nitrate in ice cores: evidence from the Dome C deep ice core, J. Geophys. Res., 105, 20565 20572, 2000

Sander, S. P., Friedl, R. R., Golden, D. M., Kurylo, M. J., Moortgat, G. K., Keller-Rudek, H., Wine, P. J., Ravishankara, A. R., Kolb, C. E., Molina, M. J., Finalyson-Pitts, B. J., Huie, R. E., and Orkin, V. L.: Chemical kinetics and photochemical data for use in atmospheric studies evaluation number 15, JPL Publications, 06-2, Pasadena, California, USA, 1-523, 2006. 
Savarino, J., Kaiser, J., Morin, S., Sigman, D. M., and Thiemens, M. H.: Nitrogen and oxygen isotopic constraints on the origin of atmospheric nitrate in coastal Antarctica, Atmos. Chem. Phys., 7, 1925-1945, doi:10.5194/acp-7-1925-2007, 2007.

Shi, G., Buffen, A. M., Hastings, M. G., Li, C., Ma, H., Li, Y., Sun, B., An, C., and Jiang, S.: Investigation of post-depositional processing of nitrate in East Antarctic snow: isotopic constraints on photolytic loss, re-oxidation, and source inputs, Atmos. Chem. Phys., 15, 9435-9453, doi:10.5194/acp-15-9435-2015, 2015.

Sjostedt, S. J., Huey, L. G., Tanner, D. J., Peischl, J., Chen, G., Dibb, J. E., Lefer, B., Hutterli, M. A., Beyersdorf, A. J., Blake, N. J., Blake, D. R., Sueper, D., Ryerson, T., Burkhart, J., and Stohl, A.: Observations of hydroxul and the sum of peroxy radicals at Summit, Greenland during summer 2003, Atmos. Environ., 41, 5122-5137, 2007.

Slusher, D. L., Huey, L. G., Tanner, D. J., Chen, G., Davis, D. D., Buhr, M., Nowak, J. B., Eisele, F. L., Kosciuch, E., Mauldin, R. L., Lefer, B. L., Shetter, R. E., and Dibb, J. E.: Measurements of pernitric acid at the South Pole during ISCAT 2000, Geophys. Res. Lett., 29, 7-1-7-4, doi:10.1029/2002GL015703, 2002

Sofen, E. D., Alexander, B., Steig, E. J., Thiemens, M. H., Kunasek, S. A., Amos, H. M., Schauer, A. J., Hastings, M. G., Bautista, J., Jackson, T. L., Vogel, L. E., McConnell, J. R., Pasteris, D. R., and Saltzman, E. S.: WAIS Divide ice core suggests sustained changes in the atmospheric formation pathways of sulfate and nitrate since the 19th century in the extratropical Southern Hemisphere, Atmos. Chem. Phys., 14, 5749-5769, doi:10.5194/acp14-5749-2014, 2014.

Thomas, J. L., Dibb, J. E., Huey, L. G., Liao, J., Tanner, D., Lefer, B., von Glasow, R., and Stutz, J.: Modeling chemistry in and above snow at Summit, Greenland - Part 2: Impact of snowpack chemistry on the oxidation capacity of the boundary layer, Atmos. Chem. Phys., 12, 6537-6554, doi:10.5194/acp-12-65372012, 2012.

Thompson, A. M.: The oxidizing capacity of the Earth's atmosphere: probable past and future changes, Science, 256, 1157$1165,1992$.

Travouillon, T., Ashley, M. C. B., Burton, M. G., Storey, J. W. V., and Loewenstein, R. F.: Atmospheric turbulence at the South Pole and its implications for astronomy, Astron. Astrophys., 400, 1163-1172, doi:10.1051/0004-6361:20021814, 2003.

UNEP/WMO: Integrated Assessment of Black Carbon and Tropospheric Ozone: Summary for Decision Makers, UNON/Publishing Services Section, Nairobi, ISO 14001:2004, 2011.

van der Werf, G. R., Morton, D. C., DeFries, R. S., Giglio, L., Randerson, J. T., Collatz, G. J., and Kasibhatla, P. S.: Estimates of fire emissions from an active deforestation region in the southern Amazon based on satellite data and biogeochemical modelling, Biogeosciences, 6, 235-249, doi:10.5194/bg-6-235-2009, 2009. van Donkelaar, A., Martin, R. V., Leaitch, W. R., Macdonald, A. M., Walker, T. W., Streets, D. G., Zhang, Q., Dunlea, E. J., Jimenez, J. L., Dibb, J. E., Huey, L. G., Weber, R., and Andreae, M. O.: Analysis of aircraft and satellite measurements from the Intercontinental Chemical Transport Experiment (INTEX-B) to quantify long-range transport of East Asian sulfur to Canada, Atmos. Chem. Phys., 8, 2999-3014, doi:10.5194/acp-8-2999-2008, 2008.
Walters, W. W., Goodwin, S. R., and Michalski, G.: Nitrogen stable isotope composition $\delta^{15} \mathrm{~N}$ of vehicle-emitted $\mathrm{NO}_{x}$, Environ. Sci. Tech., 49, 2278-2285, doi:10.1021/es505580v, 2015.

Wang, Q., Jacob, D. J., Fisher, J. A., Mao, J., Leibensperger, E. M., Carouge, C. C., Le Sager, P., Kondo, Y., Jimenez, J. L., Cubison, M. J., and Doherty, S. J.: Sources of carbonaceous aerosols and deposited black carbon in the Arctic in winter-spring: implications for radiative forcing, Atmos. Chem. Phys., 11, 1245312473, doi:10.5194/acp-11-12453-2011, 2011.

Wang, Y., Jacob, D. J., and Logan, J. A.: Global simulation of tropospheric O3-NO $\mathrm{NO}_{x}$ hydrocarbon chemistry - Part 1: Model formulation, J. Geophys. Res., 103, 10713-10725, 1998.

Wang, Y., Choi, Y., Zeng, T., Davis, D., Buhr, M., Huey, G. L., and Neff, W.: Assessing the photochemical impact of snow $\mathrm{NO}_{x}$ emissions over Antarctica during ANTCI 2003, Atmos. Environ. 41, 3944-3958, doi:10.1016/j.atmosenv.2007.01.056, 2008.

Weller, R., Minikin, A., Konig-Langlo, G., Schrems, O., Jones, A. E., Wolff, E. W., and Anderson, P. S.: Investigating possible causes of the observed diurnal variability in Antarctic $\mathrm{NO}_{y}$, Geophys. Res. Lett., 26, 2853-2856, 1999.

Wesely, M. L.: Parameterization of surface resistances to gaseous dry deposition in regional-scale numerical-models, Atmos. Environ., 23, 1293-130, 1989. Wespes, C., Emmons, L., Edwards, D. P., Hannigan, J., Hurtmans, D., Saunois, M., Coheur, P.F., Clerbaux, C., Coffey, M. T., Batchelor, R. L., Lindenmaier, R., Strong, K., Weinheimer, A. J., Nowak, J. B., Ryerson, T. B., Crounse, J. D., and Wennberg, P. O.: Analysis of ozone and nitric acid in spring and summer Arctic pollution using aircraft, ground-based, satellite observations and MOZART-4 model: source attribution and partitioning, Atmos. Chem. Phys., 12, 237-259, doi:10.5194/acp-12-237-2012, 2012.

Wild, O., Zhu, Q., and Prather, M. J.: Fast-J: accurate simulation of in- and below-cloud photolysis in global chemical models, J. Atmos. Chem., 37, 245-282, 2000.

Wolff, E. W.: Nitrate in polar ice, in: Ice Core Studies of Global Biogeochem. Cycles, NATO ASI Ser., Ser. I, 195-224, edited by: Delmas, R. J., Springer, New York, USA, 1995.

Wolff, E. W., Jones, A. E., Bauguitte, S. J.-B., and Salmon, R. A.: The interpretation of spikes and trends in concentration of nitrate in polar ice cores, based on evidence from snow and atmospheric measurements, Atmos. Chem. Phys., 8, 5627-5634, doi:10.5194/acp-8-5627-2008, 2008.

$\mathrm{Xu}$, L. and Penner, J. E.: Global simulations of nitrate and ammonium aerosols and their radiative effects, Atmos. Chem. Phys. 12, 9479-9504, doi:10.5194/acp-12-9479-2012, 2012.

Zatko, M. C. and Warren, S. G.: East Antarctic sea ice in spring: spectral albedo of snow, nilas, frost flowers, and slush; and light-absorbing impurities in snow, Ann. Glaciol., 56, 53-64, doi:10.3189/2015AoG69A574, 2015.

Zatko, M. C., Grenfell, T. C., Alexander, B., Doherty, S. J., Thomas, J. L., and Yang, X.: The influence of snow grain size and impurities on the vertical profiles of actinic flux and associated $\mathrm{NO}_{x}$ emissions on the Antarctic and Greenland ice sheets, Atmos. Chem. Phys., 13, 3547-3567, doi:10.5194/acp-13-35472013, 2013.

Zhang, L., Gong, S., Padro, J., and Barrie, L.: A size-segregated particle dry deposition scheme for an atmospheric aerosol module, Atmos. Environ., 35, 549-560, 2001. 
Zhu, C., Xiang, B., Chu, L. T., and Zhu, L.: $308 \mathrm{~nm}$ photolysis of nitric acid in the gas phase, on aluminum surfaces, and on ice films, J. Phys. Chem. A., 114, 2561-2568, doi:10.1021/jp909867a, 2010. 